Article

\title{
Municipal Solid Waste as Secondary Resource: Selectively Separating Cu(II) from Highly Saline Fly Ash Extracts by Polymer-Assisted Ultrafiltration
}

\author{
Christine Hettenkofer ${ }^{*}{ }^{\dagger}$, Stephan Fromm ${ }^{\dagger}$ and Michael Schuster \\ Division of Analytical Chemistry, Department of Chemistry, Technical University of Munich, Lichtenbergstraße 4, \\ 85748 Garching, Germany; stephan.fromm.sw@t-online.de (S.F.); michael.schuster@tum.de (M.S.) \\ * Correspondence: hettenkofer.christine@gmail.com \\ † These authors contributed equally to this work.
}

Received: 29 November 2020; Accepted: 14 December 2020; Published: 16 December 2020

\begin{abstract}
Urban mining from fly ash resulting from municipal solid waste incineration (MSWI) is becoming more and more important due to the increasing scarcity of supply-critical metals. Metal extraction from acid fly ash leaching has already been established. In this context selective $\mathrm{Cu}$ recovery is still a challenge. Therefore, our purpose was the separation of $\mathrm{Cu}$ (II) from MSWI fly ash extracts by polymer-assisted ultrafiltration (PAUF). We investigated three polyethyleneimines (PEIs) with regard to metal retention, $\mathrm{Cu}$ (II) selectivity, $\mathrm{Cu}(\mathrm{II})$ loading capacity, and the viscosity of the PEI containing solutions. A demanding challenge was the highly complex matrix of the fly ash extracts, which contain up to 16 interfering metal ions in high concentrations and a chloride content of $60 \mathrm{~g} \mathrm{~L}^{-1}$. Overcoming that, $\mathrm{Cu}$ (II) was selectively enriched and separated from real fly ash extract at $\mathrm{pH}$ 3.0. At $\mathrm{pH}$ 1.0, a PEI-free $\mathrm{Cu}(\mathrm{II})$ concentrate was obtained and PEIs could be regenerated for reuse in further separation cycles. The PAUF conditions developed at laboratory scale were successfully transferred to pilot scale, and hyperbranched PEI (HB-PEI) was found to be the most suitable reagent for PAUF in a technical scale. Moreover, HB-PEI enables photometric control of the $\mathrm{Cu}$ (II) enrichment.
\end{abstract}

Keywords: selective $\mathrm{Cu}(\mathrm{II})$ separation; sustainable waste treatment; municipal solid waste; polymer-assisted ultrafiltration; real fly ash extracts; urban mining; pilot installation

\section{Introduction}

For decades, prosperity has increased worldwide, which is reflected in a strong rise in resource consumption. To cover the resulting resource demand, the use of secondary raw materials is becoming more and more important. Processing of residues derived from municipal solid waste incineration (MSWI) contributes to a sustainable circular economy. Beneath the widely used bottom ash [1], a mixture of the finer boiler and filter ash, called fly ash, represents an attractive source for raw materials in urban mining. The chemical composition and resource potential of MSWI fly ash was intensively investigated [2-4], with $\mathrm{Zn}, \mathrm{Cu}$, and $\mathrm{Pb}$ identified as being particularly suitable due to the high concentration of these metals in MSWI fly ash and their good extractability [5].

Acid washing is an established method for extracting heavy metals from MSWI fly ash. The fly ash is treated with a hydrochloric acid solution, preferably stemming from wet flue gas cleaning in MSWI plants. Under slightly acidic conditions ( $\mathrm{pH} 3.0-4.0$ ), heavy metals are extracted with an efficiency $>90 \%$ for $\mathrm{Cd}$ and $\mathrm{Pb}$ and $70-80 \%$ for $\mathrm{Zn}$ and $\mathrm{Cu}[2,3,6-8]$. Vacuum belt filtration is used for dewatering, resulting in a chloride-rich fly ash extract containing the extracted metals and a heavy metal-poor filter cake. Acid fly ash washing is widely established in Swiss MSWI plants, but currently only two plants outside of Switzerland are treating fly ash this way (MVA Ingolstadt, Germany, and Termizo Liberec, Czech Republic). 
For the recovery of heavy metals from fly ash extract, the so-called FLUREC process is a proven method [9]. $\mathrm{Pb}, \mathrm{Cu}$, and $\mathrm{Cd}$ are precipitated by cementation with $\mathrm{Zn}$ powder and collected as metal sludge. Subsequently, solvent extraction is used for selective extraction and enrichment of Zn. From a sulfuric acid concentrate, high-grade $\mathrm{Zn}$ is then recovered by electrowinning. This process is performed in the Zuchwil MSWI plant (Switzerland).

In most MSWI plants, including MVA Ingolstadt, the extract from acid fly ash washing is processed by hydroxide precipitation during wastewater treatment. The drained sludge contains, among other components, hydroxides of $\mathrm{Zn}, \mathrm{Pb}, \mathrm{Cd}$, and $\mathrm{Cu}$. For metal recovery, the sludge may be treated outside of the MSWI plant by applying the Waelz process [10], a pyrometallurgical technique primarily used for steelwork dusts. Here, $\mathrm{Zn}$ and $\mathrm{Pb}$ are recovered as Waelz oxide, used as secondary raw material in hydrometallurgical $\mathrm{Zn}$ production, while $\mathrm{Cu}$ is slagged and therefore lost for recovery.

$\mathrm{Cu}$, however, became one of the most valuable metals through the 20th century, ranking after iron and aluminum in importance for infrastructure and technology [11]. It is commonly used in a broad range of industrial applications, becoming even more important hand-in-hand with the electrification of transport technologies. According to Elshkaki et al. [12], the $\mathrm{Cu}$ demand could rise from 275 to $350 \%$ by the year 2050 and exceed the projected $\mathrm{Cu}$ mineral resources. Consequently, preventing resource scarcity by improving the efficiency of the $\mathrm{Cu}$ cycle and enhancing $\mathrm{Cu}$ recycling rates is crucial.

In the so-called SESAM project funded by the German Federal Ministry of Education and Research (Bundesministerium für Bildung und Forschung), the resource potential of German MSWI fly ash and the recovery of valuable metals from MSWI fly ash was investigated $[4,5,13]$. Special attention was given to the acid fly ash leaching process as applied in the MSWI plant in Ingolstadt (Germany). In particular, the separation of valuable metals from the fly ash extract prior to hydroxide precipitation was targeted. In order to extend the spectrum of available techniques, the application of polymer-assisted ultrafiltration (PAUF) for selective separation of $\mathrm{Cu}$ from fly ash extract was studied.

This ultrafiltration technique is also called polymer-enhanced ultrafiltration (PEUF), polymersupported ultrafiltration (PSU), liquid-phase polymer-based retention (LPR), and polymer filtration (PF) [14]. It is based on the $\mathrm{pH}$-dependent, reversible binding of metal ions to functionalized water-soluble polymers. In a membrane ultrafiltration step, the polymer-metal complexes are retained by the membrane and remain in the retentate solution, whereas non-bound ions pass the membrane and are found in the permeate solution. Polymer-assisted ultrafiltration is a single-phase process examined for the complexation, enrichment, and separation of metal ions from wastewater.

So far, many different polymers have been studied regarding PAUF applications [15]. An outstanding and extensively investigated water-soluble polymer class are polyethyleneimines (PEIs). Their amino groups are able to form ammine complexes with various (heavy) metal ions, such as $\mathrm{Zn}(\mathrm{II}), \mathrm{Ni}(\mathrm{II})$, and $\mathrm{Cu}(\mathrm{II})$. In recent years, $\mathrm{Cu}$ (II) separation has been performed using, inter alia, branched PEI and partially ethoxylated PEI; selective retention of $\mathrm{Cu}(\mathrm{II})$ using PEI was carried out at $\mathrm{pH} \geq 3.0[16,17], \mathrm{pH} \geq 5.0[18]$, and $\mathrm{pH} \geq 6.0[19,20]$. By decreasing the $\mathrm{pH}$ value, the respective metal ion can be released from the polymer.

A challenge in PAUF is the technical implementation of the filtration step in continuous operation. The polymer held back in the ultrafiltration retentate forms a layer on the membrane surface, severely decreasing the permeate flux. In order to control the thickness of this so-called gel layer, cross- or tangential flow filtration is applied. The polymer containing retentate is passed over the membrane surface tangentially to the permeate flow at high velocity. This causes turbulence in the retentate and reduces the gel layer formation. When assessing the technical application of water-soluble polymers, determining their hydrodynamic behavior in tangential flow filtration is an important factor [21-23].

Yet despite a substantial body of research polymer-assisted ultrafiltration still has not reached wide industrial application. Up to now, only a few PAUF studies have been carried out with operation in continuous mode with a pilot installation [22,24-27]. Schulte-Bockholt et al. [28] investigated the processing of industrial phosphating rinsing baths using a PAUF pilot plant. Apart from a few other applications like metal removal from chlorine free pulp and paper industry wastewater [29] and from 
mine drainage water [30] with metal concentrations in the $\mathrm{mg} \mathrm{L}^{-1}$ range, PAUF has primarily been investigated using synthetic metal ion solutions without testing the applicability with real wastewater. To the best of our knowledge, PAUF has not yet been applied for highly complex matrices, such as extracts of municipal solid waste or other applications in terms of urban mining.

In our study, the selective enrichment and separation of $\mathrm{Cu}(\mathrm{II})$ from MSWI fly ash extracts by PAUF was investigated. The high salinity of fly ash extracts with competing ions in concentrations up to the $\mathrm{g} \mathrm{L}^{-1}$ range, is extremely challenging not only for PAUF applications. Three commercially available PEIs were examined in laboratory-scale experiments with fly ash extracts from two MSWI plants. Based on these results, the hydrodynamic behavior of hyperbranched PEI was studied in the operation of a membrane ultrafiltration pilot plant. The technical scale retention, enrichment, purification, and regeneration of $\mathrm{Cu}(\mathrm{II})$ was thoroughly investigated and is discussed in the following sections.

\section{Materials and Methods}

\subsection{Elemental Analysis of Fly Ash Extracts}

Waste incineration plants of Ingolstadt, Germany (MVA Ingolstadt), and Zuchwil, Switzerland (KEBAG Zuchwil), kindly provided fly ash extract samples. The samples were filtered using syringe filter holders ( $0.45 \mu \mathrm{m}$, polyether sulfone; Sartorius, Göttingen, Germany). For each sample, 60 elements were analyzed by matrix-adapted inductively coupled plasma optical emission spectrometry (ICP-OES; iCAP 7600 Duo, Thermo Fisher Scientific, Waltham, MA, USA). The corresponding results were validated by inductively coupled plasma mass spectrometry (ICP-MS; Agilent 7900, Santa Clara, CA, USA). Chloride concentrations of the fly ash extracts were determined by potentiometric titration with silver nitrate solution (Titrando 904, Metrohm, Herisau, Switzerland).

\subsection{Laboratory-Scale PAUF Experiments}

\subsubsection{Reagents}

Hyperbranched polyethyleneimine (HB-PEI; MW 25 kDa, 56 wt.\% in $\mathrm{H}_{2} \mathrm{O}$; Lupasol HF) and modified polyethyleneimine (MOD-PEI; MW $\sim 2000 \mathrm{kDa}, 24 \mathrm{wt} . \%$ in $\mathrm{H}_{2} \mathrm{O}$; Lupasol SK) were kindly supplied by BASF SE (Ludwigshafen, Germany). Partially ( $80 \%$ ) ethoxylated polyethyleneimine (PE-PEI; MW 70 kDa, 35-40 wt.\% in $\mathrm{H}_{2} \mathrm{O}$ ) was purchased from Sigma Aldrich (St. Louis, MO, USA). Sodium hydroxide (for analysis; Merck, Darmstadt, Germany) and nitric acid (65\%, for analysis; Merck) were used to adjust the working $\mathrm{pH}$ of the feed solution.

\subsubsection{Ultrafiltration Setup and Analytical Methods}

The ultrafiltration system consisted of a peristaltic pump (Ismatec, Zürich, Switzerland), an ultrafiltration module (Sartorius, Göttingen, Germany), a pH electrode (SI Analytics, Mainz, Germany), and a pH meter (Schott, Mainz, Germany) (Figure S1). The feed solution was magnetically stirred. Vivaflow ${ }^{\circledR} 50$ filtration units (Sartorius) consisting of a flat membrane made of polyether sulfone (molecular weight cut-off $(\mathrm{MWCO})=5$ or $10 \mathrm{kDa}, \mathrm{A}=50 \mathrm{~cm}^{2}$ ) were used as ultrafiltration modules. During the ultrafiltration process, different material flows appear, while the feed solution is piped through the ultrafiltration membrane. Permeate is defined as the flow passing the membrane, whereas retentate is the flow retained by the membrane. Sampling of feed (1, Figure S1) and permeate (2, Figure S1) was performed $15 \mathrm{~min}$ after each $\mathrm{pH}$ adjustment. All permeate and feed samples were analyzed by ICP-OES. The polymer concentration in permeate and feed was determined by total organic carbon (TOC) measurement using a TOC analyzer (Shimadzu, Kyoto, Japan). Calibration of the latter was performed by determining the TOC of various concentrations of the respective polymer in ultrapure water. The resulting metal and polymer retentions were calculated using Equation (1):

$$
\mathrm{R}_{i}[\%]=\left(1-\left(\mathrm{c}_{p, i} / \mathrm{c}_{f, i}\right)\right) \times 100
$$


where $i$ is the metal species or polymer, $\mathrm{R}_{i}$ is retention of $i, \mathrm{c}_{p, i}$ is concentration of $i$ in the permeate, and $c_{f, i}$ is concentration of $i$ in the feed.

\subsubsection{Pretreatment of PEIs}

Polydisperse substances such as (modified) PEIs show a broad molar mass distribution. Low molecular weight fractions have to be removed to ensure that the polymers are retained by the membrane in the subsequent PAUF experiments. Thus, the polymers were pretreated in an ultrafiltration step, to remove small polymer molecules that can pass the membrane. For this purpose, ultrafiltration membranes $(\mathrm{MWCO}=10 \mathrm{kDa})$ were used and the permeate was led into a separate vessel. During precleaning, polymer concentration in permeate and feed was continuously determined by TOC measurement and the polymer retention was calculated according to Equation (1). The precleaning of the polymer was terminated after reaching a polymer retention of more than $98 \%$.

\subsubsection{Determination of Metal Retention Behavior of PEIs}

Prior to their use in ultrafiltration experiments, the fly ash extracts were filtered using syringe filter holders. The feed solutions of the PAUF experiments consisted of diluted fly ash extract (1:2 in ultrapure water) from MVA Ingolstadt and KEBAG Zuchwil and a final concentration (7.9-10.0 g L $\left.{ }^{-1}\right)$ of HB-PEI, PE-PEI, or MOD-PEI. Control experiments without the addition of polymer were also carried out. The ultrafiltration experiments using membranes with a MWCO of $10 \mathrm{kDa}$ were carried out in total recirculation mode, which means permeate and retentate flows were returned to the feed. At first, the $\mathrm{pH}$ value of the feed solutions was decreased to $\mathrm{pH} 0.7-1.0$ by the addition of nitric acid $(65 \%)$. Afterwards, the $\mathrm{pH}$ was successively increased up to $5.0-5.8$ by the addition of sodium hydroxide solution (6M). Finally, to investigate the metal release from the PEIs, the pH was decreased to 1.0. The permeate and feed samples that were taken after each $\mathrm{pH}$ adjustment were analyzed by ICP-OES. Additionally, TOC measurements were carried out to control the polymer retention.

In addition, all feed samples were centrifuged for $10 \mathrm{~min}$ at $4427 \mathrm{~g}$ (Z 206A, Hermle, Wehingen, Germany) and the resulting supernatants were analyzed by ICP-OES.

\subsubsection{Determination of $\mathrm{Cu}(\mathrm{II})$ Loading Capacity of PEIs}

To investigate the maximum $\mathrm{Cu}(\mathrm{II})$ loading capacity of each PEI, further ultrafiltration experiments were carried out. The feed solutions consisted of fly ash extract from KEBAG Zuchwil and HB-PEI at a final concentration of $4.6 \mathrm{~g} \mathrm{~L}^{-1}$, PE-PEI at $4.7 \mathrm{~g} \mathrm{~L}^{-1}$, and MOD-PEI at $3.7 \mathrm{~g} \mathrm{~L}^{-1}$. Membranes with a MWCO of $5 \mathrm{kDa}$ were used. During the whole experiment, the $\mathrm{pH}$ was kept constant at 4.0 (HB-PEI, MOD-PEI) or 4.3 (PE-PEI) and the ultrafiltration system was operated in total recirculation mode (see Section 2.2.4). After the $\mathrm{pH}$ was adjusted to 4.0 or 4.3 , the $\mathrm{Cu}$ (II) concentration of the feed solutions was stepwise increased by adding a $\mathrm{Cu}$ (II) nitrate trihydrate solution (for analysis; Merck) diluted with ultrapure water. Finally, $\mathrm{pH}$ was adjusted to 1.0 by adding nitric acid (65\%) to examine the $\mathrm{Cu}$ (II) release from the PEIs. Fifteen minutes after each $\mathrm{Cu}(\mathrm{II})$ addition and after adjusting the final $\mathrm{pH}$ to 1.0, samples of permeate and feed were taken and analyzed by ICP-OES and TOC.

\subsection{Viscosity Determination of Aqueous Polymer Solutions}

The viscosity of aqueous solutions containing HB-PEI, PE-PEI, and MOD-PEI was determined using a DV-III+ rheometer (Brookfield, Middleboro, MA, USA) with cone/plate setup (CPE40). Temperature was controlled at $30{ }^{\circ} \mathrm{C}$ by a circulation thermostat (LAUDA RE204, Koenigshofen, Germany). In order to remove membrane-permeable size fractions of the polymers, pretreatment was performed according to Section 2.2.3. 


\subsection{Pilot-Scale PAUF Experiments}

\subsubsection{PAUF Pilot Plant}

For pilot-scale PAUF experiments, a tangential flow ultrafiltration plant according to Figure 1 was used (Andreas Junghans $\mathrm{GmbH}$, Frankenberg/Sachsen, Germany). Three ceramic multichannel tubular membranes $\left(\mathrm{CA}-\mathrm{TiO}_{2} / \mathrm{Al}_{2} \mathrm{O}_{3}\right.$; Inopor, Veilsdorf, Germany) with a mean pore width of $10 \mathrm{~nm}$ were mounted in the membrane module.

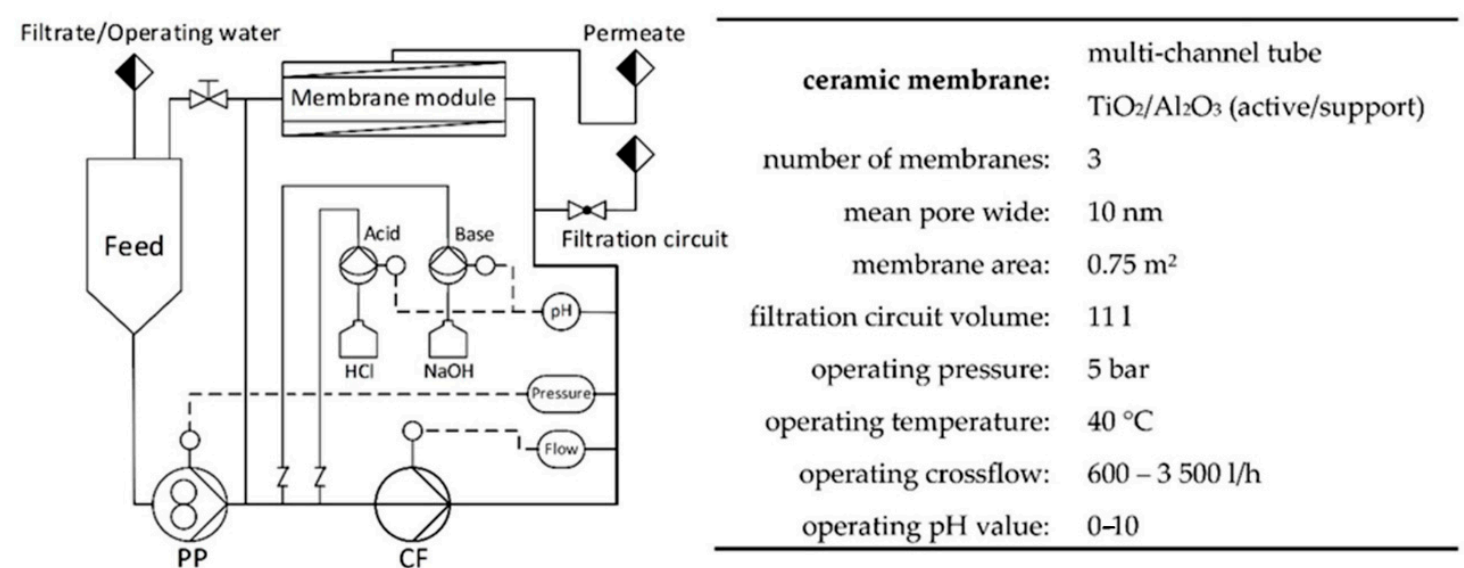

Figure 1. Scheme and operating data of tangential flow ultrafiltration pilot scale plant used for $\mathrm{Cu}$ (II) enrichment and separation (Andreas Junghans $\mathrm{GmbH}$, Frankenberg/Sachsen, Germany). PP, pressure pump; CF, cross-flow pump.

The pilot plant was operated with HB-PEI (Lupasol HF, MW $\sim 25 \mathrm{kDa}, 56 \mathrm{wt} . \%$ in $\mathrm{H}_{2} \mathrm{O}$ ). For startup, the polymer solution was added into the feed tank and fed to the filtration circuit. Polymer solutions were pretreated with water in order to flush out the membrane-permeant size fraction until polymer retention $>99.8 \%$ was reached. In operation, the polymer was trapped in the filtration circuit (volume $11 \mathrm{~L}$ ) and the feed reservoir was polymer-free. Polymer solutions were reused in various experiments after regeneration at $\mathrm{pH} 1$.

The parts of the pilot plant that were in contact with polymer containing media were made of PVC. A gear pump was used to feed solutions from the feed reservoir into the filtration circuit and to release the buildup of filtration pressure. Cross-flow was generated by a centrifugal pump and regulated by automatic flow measurement. The $\mathrm{pH}$ value in the filtration circuit was continuously measured and controlled by automatic dosing of $6 \mathrm{M}$ hydrochloric acid and $10 \mathrm{M}$ sodium hydroxide solution directly into the filtration circuit. For tempering of the pilot plant, a heat exchanger was optionally mounted in the filtration circuit but removed during the experiments in order to avoid additional flow resistance. Heat generated by the cross-flow pump was sufficient to keep the temperature in the filtration circuit at $40{ }^{\circ} \mathrm{C}$. The pilot plant provided a human-machine interface based on Siemens SIMATIC S7.

\subsubsection{Fly Ash Extracts Used for Pilot-Scale PAUF Experiments}

For investigations with the pilot plant, fly ash extract from the acid washing at the Ingolstadt MSWI plant was used. Suspended matter was allowed to settle and the fly ash extract was then filtered through a bag filter $(50 \mu \mathrm{m})$. The extract taken from the MSWI plant contained $0.13 \mathrm{~g} \mathrm{~L}^{-1}$ of $\mathrm{Cu}$ (II). In order to additionally investigate the PAUF treatment of fly ash extract with a higher $\mathrm{Cu}$ (II) concentration, a second extract with $0.70 \mathrm{~g} \mathrm{~L}^{-1}$ of $\mathrm{Cu}$ (II) was achieved by adding $\mathrm{Cu}\left(\mathrm{NO}_{3}\right)_{2} \cdot 3 \mathrm{H}_{2} \mathrm{O}$ to the extract taken from the MSWI plant. The evaluation was focused on the elements with the highest concentration in the fly ash extract $\left(\mathrm{Pb}, \mathrm{Zn}, \mathrm{Ca}\right.$, and $\mathrm{Cl}^{-}$, listed in Table 1$)$. 
Table 1. Concentration of elements $\mathrm{Zn}, \mathrm{Pb}, \mathrm{Cu}, \mathrm{Ca}$, and $\mathrm{Cl}^{-}$in municipal solid waste incineration (MSWI) fly ash extract used for retention experiments. ${ }^{*}$ Achieved by addition of $\mathrm{CuNO}_{3}$.

\begin{tabular}{cccccc}
\hline $\mathbf{Z n}$ & $\mathbf{P b}$ & $\mathbf{C u}$ & $\mathbf{C a}$ & $\mathbf{C l}^{-}$ & \\
\hline 2.4 & 0.78 & $0.13 / 0.70 *$ & 6 & 81 & $\mathrm{~g} \mathrm{~L}^{-1}$ \\
\hline
\end{tabular}

\subsubsection{Pilot Plant Filtration Data}

The permeate flux and specific power consumption (pressure and cross-flow pump) of the pilot plant were determined at $40^{\circ} \mathrm{C}$ and a transmembrane pressure (TMP) of 5 bar, depending on the polymer concentration and tangential velocity in the filtration circuit. The pilot plant was filled with fly ash extract and operated in recirculation mode (permeate was recirculated into the feed reservoir). Pretreated HB-PEI solution was stepwise added to the feed reservoir and fed into the filtration circuit.

\subsubsection{Selective $\mathrm{Cu}(\mathrm{II})$ Retention}

The filtration circuit was filled with a $4 \mathrm{~g} \mathrm{~L}^{-1}$ solution of pretreated HB-PEI in water. To start the retention experiment, fly ash extract was continuously fed into the filtration circuit, with the $\mathrm{pH}$ value kept at 3.0. Samples were taken from the filtration circuit and analyzed by ICP-OES. Retention experiments were ended after $53 \mathrm{~L}$ (extract with $0.13 \mathrm{~g} \mathrm{~L}^{-1} \mathrm{Cu}$ ) or $21 \mathrm{~L}$ (extract with $0.7 \mathrm{~g} \mathrm{~L}^{-1} \mathrm{Cu}$ ).

\subsubsection{Rinsing of $\mathrm{Cu}(\mathrm{II})$ Loaded Preconcentrates with Water}

Rinsing of the $\mathrm{Cu}(\mathrm{II})$ loaded polymer concentrate was performed using concentrates from the $\mathrm{Cu}$ (II) retention experiments (Section 2.4.4). The filtration circuit was filled with polymer containing fly ash extract ( $4 \mathrm{~g} \mathrm{~L}^{-1} \mathrm{HB}-\mathrm{PEI}, 2.0 \mathrm{~g} \mathrm{~L}^{-1} \mathrm{Zn}, 0.7 \mathrm{~g} \mathrm{~L}^{-1} \mathrm{~Pb}, 4.7 \mathrm{~g} \mathrm{~L}^{-1} \mathrm{Ca}$ ) and the pilot plant was operated at $\mathrm{pH} 3.0$ with water as feed for $1 \mathrm{~h}$. Samples were taken from the filtration circuit and analyzed by ICP-OES.

Thickening of the polymer solution was achieved by feeding fly ash extract with $4 \mathrm{~g} \mathrm{~L}^{-1} \mathrm{HB}-\mathrm{PEI}$ to the filtration circuit until a polymer concentration of $25 \mathrm{~g} \mathrm{~L}^{-1} \mathrm{HB}-\mathrm{PEI}$ was reached.

$\mathrm{Cu}$ (II) retention during rinsing was optimized using $25 \mathrm{~g} \mathrm{~L}^{-1} \mathrm{HB}-\mathrm{PEI}$ loaded with $200 \mathrm{mg}$ of $\mathrm{Cu}(\mathrm{II}) / \mathrm{g}$ polymer. Rinsing was carried out with water for $1 \mathrm{~h}$ at $\mathrm{pH} 4.0,3.5$, and 3.0. Samples were taken from the filtration circuit and analyzed by ICP-OES.

\subsubsection{Recovery of $\mathrm{Cu}(\mathrm{II})$ and Regeneration of Polyethyleneimine}

Recovery of $\mathrm{Cu}$ (II) from the filtration circuit was performed using a concentrate received after rinsing ( $4 \mathrm{~g} \mathrm{~L}^{-1} \mathrm{HB}$-PEI, $0.7 \mathrm{~g} \mathrm{~L}^{-1} \mathrm{Cu}(\mathrm{II})$ ). The $\mathrm{pH}$ was decreased to 1.0 and the pilot plant was operated with water. Samples were taken from the filtration circuit and analyzed by ICP-OES.

\subsection{Monitoring Cu(II) Enrichment and Release by UV-Vis Spectroscopy}

Polyethyleneimine and $\mathrm{Cu}$ (II) form stable tetraamminecopper(II) complexes, which absorb light within the visible spectral range and appear in blue. Therefore, we investigated a possible photometric control of the $\mathrm{Cu}(\mathrm{II})$ enrichment and release.

UV-vis spectra of feed samples resulting from the $\mathrm{Cu}(\mathrm{II})$ loading experiments with HB-PEI (see Section 2.2.5) were recorded with a Lambda 35 UV-vis spectrometer (Perkin Elmer, Waltham, MA, USA) using polymethylmethacrylate sample cuvettes (VWR, Darmstadt, Germany). Solutions of Cu(II) nitrate trihydrate in ammonium hydroxide and in ultrapure water were prepared and investigated, functioning as comparative samples representing $\mathrm{Cu}(\mathrm{II})$ ammine complexes without polymer. 


\section{Results and Discussion}

\subsection{Metal Retention of Different PEIs in MSWI Fly Ash Extracts}

Three different polyethyleneimines were investigated regarding their retention behavior towards all metal species contained in the fly ash extracts from MVA Ingolstadt and KEBAG Zuchwil. Composition of the fly ash extracts was previously analyzed; the resulting main metal components and chloride concentrations are shown in Table S1.

Figure 2 shows the retention of $\mathrm{Cd}(\mathrm{II}), \mathrm{Cu}(\mathrm{II}), \mathrm{Ni}(\mathrm{II}), \mathrm{Pb}(\mathrm{II}), \mathrm{Zn}(\mathrm{II}), \mathrm{Fe}(\mathrm{III})$, and $\mathrm{Sb}(\mathrm{V})$ using HB-PEI (Figure 2a,b), PE-PEI (Figure 2c,d), and MOD-PEI (Figure 2e,f). HB-PEI contains primary, secondary, and tertiary amino groups. Each PEI was investigated using the fly ash extracts from both MVA Ingolstadt (Figure 2b,d,f) and KEBAG Zuchwil (Figure 2a,c,e).
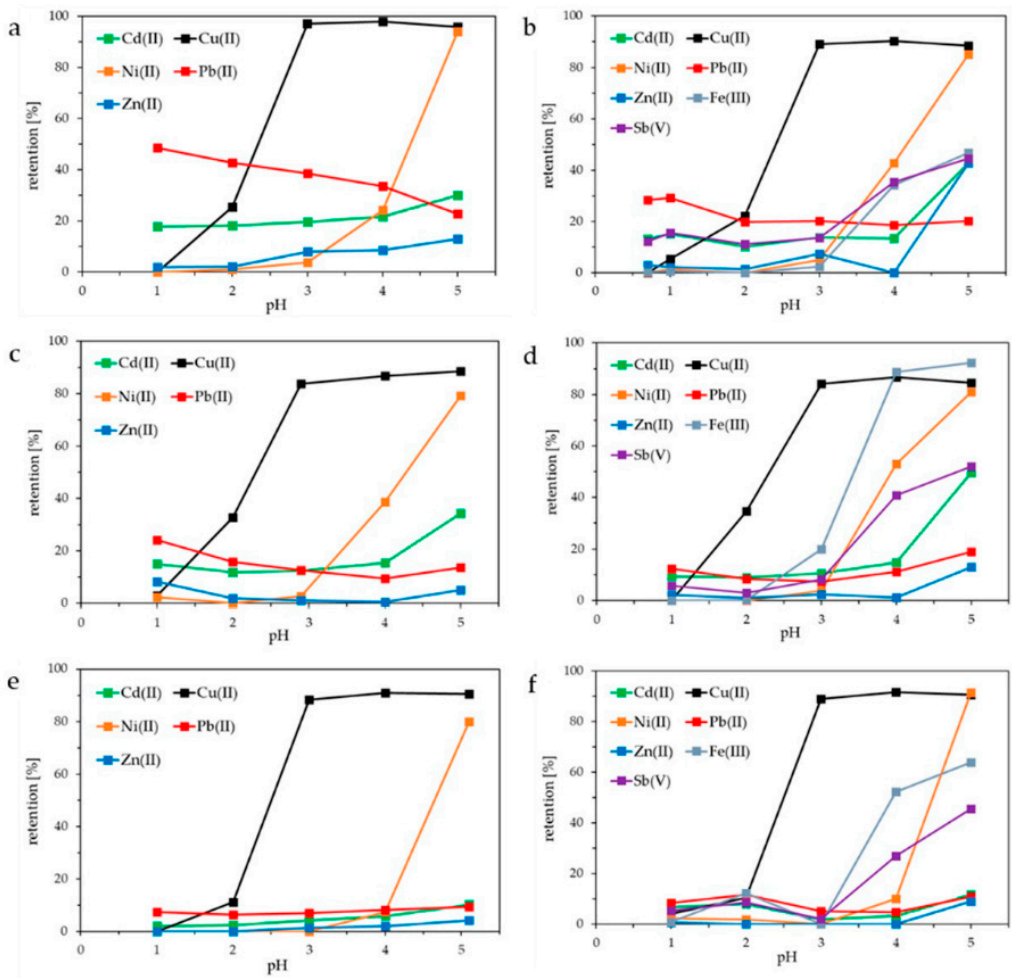

Figure 2. Influence of $\mathrm{pH}$ on the retention of $\mathrm{Cd}(\mathrm{II}), \mathrm{Cu}(\mathrm{II}), \mathrm{Ni}(\mathrm{II}), \mathrm{Pb}(\mathrm{II}), \mathrm{Zn}(\mathrm{II}), \mathrm{Fe}(\mathrm{III})$, and $\mathrm{Sb}(\mathrm{V})$ using fly ash extracts from KEBAG Zuchwil and MVA Ingolstadt: $(\mathbf{a}, \mathbf{b})$ hyperbranched polyethyleneimine $\left(\right.$ HB-PEI) $=10.0 \mathrm{~g} \mathrm{~L}^{-1}$ (Zuchwil), $7.9 \mathrm{~g} \mathrm{~L}^{-1}$ (Ingolstadt); (c,d) partially ethoxylated polyethyleneimine $(\mathrm{PE}-\mathrm{PEI})=9.4 \mathrm{~g} \mathrm{~L}^{-1}$ (Zuchwil), $7.7 \mathrm{~g} \mathrm{~L}^{-1}$ (Ingolstadt); (e,f) modified polyethyleneimine (MOD-PEI) = $9.7 \mathrm{~g} \mathrm{~L}^{-1}$ (Zuchwil), $8.0 \mathrm{~g} \mathrm{~L}^{-1}$ (Ingolstadt).

As illustrated in Figure $2 \mathrm{a}-\mathrm{f}, \mathrm{Cu}(\mathrm{II})$ is the only metal ion retained at approximately $100 \%$ from pH 3.0 upwards. At this $\mathrm{pH}, \mathrm{Cd}(\mathrm{II})$ and $\mathrm{Pb}(\mathrm{II})$ are retained at about $10 \%$ using PE-PEI (Figure 2c,d), and 15-30\% using HB-PEI (Figure 2a,b). The fly ash extract from MVA Ingolstadt additionally contains $\mathrm{Fe}(\mathrm{III})$ and $\mathrm{Sb}(\mathrm{V})$, which are increasingly retained by the membrane starting from $\mathrm{pH} 3.0$ on (Figure 2b,d,f).

As shown in Table 2, both fly ash extracts contained many more metal ions than depicted in Figure 2. The retention of $\mathrm{Li}, \mathrm{Na}, \mathrm{K}, \mathrm{Rb}, \mathrm{Mg}, \mathrm{Ca}, \mathrm{Sr}, \mathrm{Si}, \mathrm{Al}$, and $\mathrm{Mn}$ was also investigated in the same PAUF experiments described in Figure 2. All were barely retained by the membrane, as can be seen in Table 2. Regarding the monovalent alkali metal ions that was to be expected, however, the nonbinding especially of divalent alkaline earth metal ions is a crucial result regarding the target $\mathrm{Cu}$ (II) selectivity in the treatment of highly saline fly ash extracts. 
Table 2. Retention of $\mathrm{Li}(\mathrm{I}), \mathrm{Na}(\mathrm{I}), \mathrm{K}(\mathrm{I}), \mathrm{Rb}(\mathrm{I}), \mathrm{Mg}(\mathrm{II}), \mathrm{Ca}(\mathrm{II}), \mathrm{Sr}(\mathrm{II}), \mathrm{Al}(\mathrm{III}), \mathrm{Si}(\mathrm{IV})$, and $\mathrm{Mn}(\mathrm{II})$ using fly ash extracts from KEBAG Zuchwil and MVA Ingolstadt and HB-PEI, PE-PEI, and MOD-PEI polymers.

\begin{tabular}{ccccccc}
\hline & \multicolumn{5}{c}{ Retention } \\
\cline { 2 - 6 } Elements & Fly Ash Extract from KEBAG Zuchwil & \multicolumn{1}{c}{ Fly Ash Extract from MVA Ingolstadt } \\
\hline & HB-PEI & PE-PEI & MOD-PEI & HB-PEI & PE-PEI & MOD-PEI \\
\hline $\begin{array}{l}\mathrm{Li}, \mathrm{Na}, \mathrm{K}, \mathrm{Rb}, \mathrm{Mg}, \\
\mathrm{Ca}, \mathrm{Sr}, \mathrm{Al}, \mathrm{Si}, \mathrm{Mn}\end{array}$ & $<6 \%$ & $<4 \%$ & $<9 \%$ & $<8 \%$ & $<3 \%$ & $<6 \%$ \\
\hline
\end{tabular}

The high $\mathrm{Cu}(\mathrm{II})$ retention observed is based on the interaction of $\mathrm{Cu}(\mathrm{II})$ with the respective PEI. $\mathrm{Cu}$ (II) forms tetraamminecopper(II) complexes with amine groups of the three PEIs. Ni(II) and $\mathrm{Zn}$ (II) are retained by forming ammine complexes as well but only at $\mathrm{pH}>3.0$.

To clarify the observed retention of additional metal ions (Figure 2a-f), ultrafiltration experiments were carried out using fly ash extract without the addition of PEI. The results obtained are shown in Figure S2.

To some extent, $\mathrm{Pb}, \mathrm{Fe}$, and $\mathrm{Sb}$ were retained in the PAUF experiments described above, but they also showed similar retention in the experiments without the addition of PEI (Figure S2). During these experiments, visible turbidity of the feed solutions was observed; the feed samples were centrifuged and the supernatants were analyzed. A continuously decreasing Fe concentration above $\mathrm{pH} 3.0$ was observed: Between pH 3.0 and 5.0 Fe(II) and Fe(III) may both exist, but Fe(II)-hydroxide requires a $\mathrm{pH}>7.0$ for precipitation [3]. Therefore, Fe(III) was precipitated as solid iron(III)oxide hydrate and retained by the ultrafiltration membrane in the PAUF experiments (Figure $2 \mathrm{~b}, \mathrm{~d}, \mathrm{f}$ ).

The $\mathrm{Sb}$ concentration of the centrifuged feed samples also decreased above $\mathrm{pH}$ 3.0. This could occur due to the precipitation of $\mathrm{Na}\left[\mathrm{Sb}(\mathrm{OH})_{6}\right]$, formed with sodium ions contained in the fly ash extract and also resulting from adjusting the $\mathrm{pH}$ with sodium hydroxide. Furthermore, $\mathrm{Sb}(\mathrm{V})$ and $\mathrm{Sb}(\mathrm{III})$ may coexist [31], enabling coprecipitation of $\mathrm{Sb}(\mathrm{OH})_{3}$ with $\mathrm{Fe}(\mathrm{III})$ oxide hydrate. Similar retention progression of antimony and iron, shown in Figure $2 b, f$, indicates this.

$\mathrm{Pb}(\mathrm{II})$ was retained to different degrees using HB-PEI, PE-PEI, and MOD-PEI (Figure 2) and also without the addition of PEI (Figure S2). Dissolved $\mathrm{Pb}^{2+}$ forms lead chloro complexes such as $[\mathrm{PbCl}]^{+},\left[\mathrm{PbCl}_{3}\right]^{-},\left[\mathrm{PbCl}_{4}\right]^{2-}$ and/or hardly soluble $\mathrm{PbCl}_{2}$ in the presence of $60 \mathrm{~g} \mathrm{~L}^{-1}$ chloride [32], as contained in the fly ash extracts. Weibel et al., thoroughly investigated Pb-chloro complex formation in fly ash extract and identified $\left[\mathrm{PbCl}_{3}\right]^{-}$and $\left[\mathrm{PbCl}_{4}\right]^{2-}$ as the mainly present species [3,6]. Presumably, a certain percentage of the $\mathrm{Pb}(\mathrm{II})$ binds to protonated amino groups of the PEIs via these negatively charged chloro complexes. Especially tertiary amino groups of polyethyleneimine may act as anion exchangers and therefore bind negatively charged chloro complexes. The lead retention observed in the experiments without $\mathrm{PEI}$, however, may arise from lead precipitated as $\mathrm{PbCl}_{2}$.

As shown in Figure 2a-d, Cd(II) was also retained to a small extent. This may be due to the formation of stable negatively charged $\mathrm{Cd}(\mathrm{II})$ chloro complexes binding to polyethyleneimine analogous to $\mathrm{Pb}$ (II) [33]. Weibel et al., found $\left[\mathrm{CdCl}_{4}\right]^{2-}$ and $\left[\mathrm{CdCl}_{3}\right]^{-}$to be the dominant $\mathrm{Cd}$-chloro complexes formed in fly ash extracts [6]. Cadmium, however, did not show any retention without PEI (Figure S2), because $\mathrm{CdCl}_{2}$ is water-soluble, in contrast to $\mathrm{PbCl}_{2}$.

Conclusively, at $\mathrm{pH}$ 3.0, $\mathrm{Cu}$ (II) was the only metal ion being bound to the investigated PEIs via metal complex formation with amine groups.

After enrichment, $\mathrm{Cu}$ (II) has to be released from the polyethyleneimine in order to achieve selective $\mathrm{Cu}$ (II) separation. At the same time, a complete metal release means regeneration of the polymer, which can then be reused in further enrichment cycles.

We investigated the $\mathrm{Cu}(\mathrm{II})$ release by decreasing the $\mathrm{pH}$ of the feed solution at the end of each PAUF experiment. For all six feed solutions shown in Figure 2, $\mathrm{Cu}(\mathrm{II})$ retention at $\mathrm{pH} 1.0$ was $0 \%$ using fly ash extract from KEBAG Zuchwil (Figure 2a,c,e) and 4-5\% using fly ash extract from MVA 
Ingolstadt (Figure $2 \mathrm{~b}, \mathrm{~d}, \mathrm{f})$. Therefore, $\mathrm{Cu}(\mathrm{II})$ was successfully released from all investigated PEIs at $\mathrm{pH} \leq 1$.

Summarizing the sorption behavior of MOD-PEI, $\mathrm{Cu}(\mathrm{II})$ was selectively separated at $\mathrm{pH} 3.0$ from 16 different metal ions, including additional heavy metals, alkaline and alkaline earth metals. Moreover, the very high chloride concentration of $60 \mathrm{~g} \mathrm{~L}^{-1}$ in the highly saline fly ash extracts did not influence the $\mathrm{pH}$-dependent $\mathrm{Cu}$ (II) chelating behavior. This also applies for HB-PEI [19] and PE-PEI [20]. The selective $\mathrm{Cu}$ (II) separation from real fly ash extract is even more exceptional, as the $\mathrm{Cu}$ (II) concentration in fly ash extracts is up to 380 times lower compared to interfering ions, such as alkaline (earth) metals or zinc. The highest selectivity regarding $\mathrm{Cu}(\mathrm{II})$ separation was achieved with MOD-PEI (Figure 2e,f). Compared to HB-PEI and PE-PEI MOD-PEI provides a lower number of amino groups. This leads to an early displacement of other competing metal ions by $\mathrm{Cu}$ (II) because $\mathrm{Cu}$ (II) forms the most stable transition-metal complex compounds among all metal ions present in the investigated fly ash extracts [34].

\subsection{Copper Loading Capacity of HB-PEI, PE-PEI, and MOD-PEI Using Fly Ash Extract}

Besides the qualitative characterization of the metal binding behavior of the PEIs, Cu loading capacity was also determined. During the stepwise addition of $\mathrm{Cu}(\mathrm{II})$ nitrate trihydrate to the feed solution of the PEIs in fly ash extract from KEBAG Zuchwil, each of the three feed solutions became deeper blue. The $\mathrm{Cu}$ loading was visible due to the formation of blue tetraamminecopper(II) complexes formed by dissolved $\mathrm{Cu}$ (II) and the amino groups of the polymers. As illustrated in Figure 3, HB-PEI shows the highest loading capacity for $\mathrm{Cu}$ (II) closely followed by PE-PEI and with a much higher distance MOD-PEI.

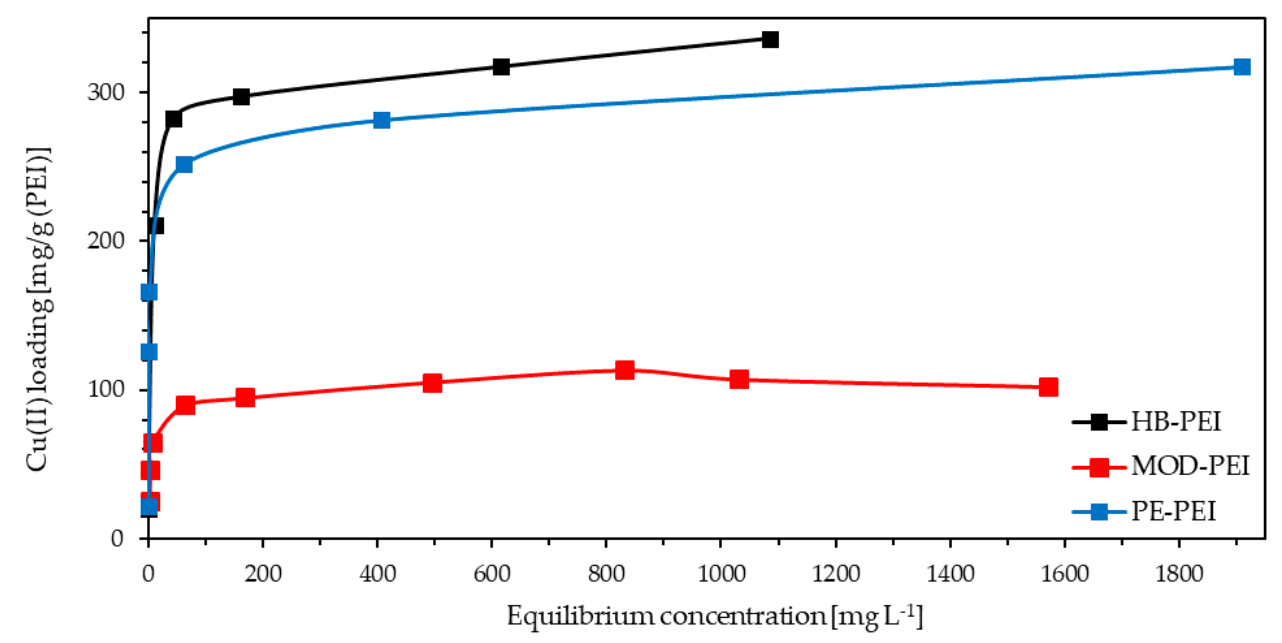

Figure 3. $\mathrm{Cu}(\mathrm{II})$ loading capacity for HB-PEI $\left(4.6 \mathrm{~g} \mathrm{~L}^{-1}\right)$, PE-PEI $\left(4.7 \mathrm{~g} \mathrm{~L}^{-1}\right)$, and MOD-PEI $\left(3.7 \mathrm{~g} \mathrm{~L}^{-1}\right)$ using fly ash extract (KEBAG Zuchwil).

The determined $\mathrm{Cu}$ (II) loading capacities of HB-PEI and PE-PEI are in the same range as stated in [20]. However, the experiments described in this study were not carried out with real wastewater, but with a synthetic solution containing only copper sulfate. As a remarkable result, the very high concentration of interfering ions in real fly ash extract did not have any influence on the $\mathrm{Cu}$ (II) loading capacity of polyethyleneimines. The $\mathrm{Cu}$ loading capacity of PE-PEI is slightly lower compared to HB-PEI, because the amino groups are partially ethoxylated and therefore not available for $\mathrm{Cu}(\mathrm{II})$ binding. MOD-PEI is even more modified, which leads to an additional reduction of the $\mathrm{Cu}$ loading capacity: Even though MOD-PEI showed the highest selectivity for $\mathrm{Cu}$ (II) (see Section 3.1), its low $\mathrm{Cu}$ loading capacity restricts the applicability for $\mathrm{Cu}$ enrichment. 


\subsection{Viscosity of PEI Solutions}

The viscosity of pretreated aqueous MOD-PEI, HB-PEI, and PE-PEI solutions was investigated. The membrane-permeant size fraction of the polymers was removed before measurement according to Section 2.2.3. Polymer concentrations up to $75 \mathrm{~g} \mathrm{~L}^{-1}$ were considered at a temperature of $30^{\circ} \mathrm{C}$.

The obtained data are given in Table 3 . The viscosity of the aqueous solutions rose with increasing polymer concentration. Solutions of HB-PEI $(\mathrm{Mw} \approx 25 \mathrm{kDa}$ ) showed higher viscosity than solutions of PE-PEI (Mw $\approx 70 \mathrm{kDa}$ ), but both remained fluid even at $75 \mathrm{~g} \mathrm{~L}^{-1}$ polymer. MOD-PEI (Mw $\left.\approx 2000 \mathrm{kDa}\right)$ showed far higher viscosity, with gel being formed at $>20 \mathrm{~g} \mathrm{~L}^{-1}$ polymer.

Table 3. Dynamic viscosity of aqueous PEI solutions $\left(30^{\circ} \mathrm{C}\right)$. Membrane-permeant size fraction was removed before measurement. Gel was formed with $>20 \mathrm{~g} \mathrm{~L}^{-1} \mathrm{MOD}-\mathrm{PEI}$.

\begin{tabular}{ccccccccc}
\hline Concentration & $\mathbf{-}$ & $\mathbf{1}$ & $\mathbf{5}$ & $\mathbf{1 0}$ & $\mathbf{2 5}$ & $\mathbf{5 0}$ & $\mathbf{7 5}$ & $\mathbf{g ~ L}^{-\mathbf{1}}$ \\
\hline MOD-PEI & 0.78 & 1.7 & 3.6 & 5.5 & - & - & - & $\mathrm{mPa} \cdot \mathrm{s}$ \\
PE-PEI & 0.78 & 0.82 & 0.86 & 0.89 & 1.1 & 1.4 & 1.8 & $\mathrm{mPa} \cdot \mathrm{s}$ \\
HB-PEI & 0.78 & 0.84 & 0.89 & 0.95 & 1.2 & 1.9 & 3.1 & $\mathrm{mPa} \cdot \mathrm{s}$ \\
\hline
\end{tabular}

Solutions of HB-PEI and PE-PEI provide a viscosity that is low enough for efficient treatment in tangential flow ultrafiltration, although if very high polymer concentrations in PAUF are desired, the use of PE-PEI may be advantageous [21]. Application of very-high-molecular-weight polymers in PAUF, such as MOD-PEI, is disadvantageous. Even at moderate polymer concentrations, the aqueous solutions cannot be treated properly in tangential flow ultrafiltration.

\subsection{Operating Data of PAUF Pilot Plant Using HB-PEI}

Operating data of the PAUF pilot plant were investigated by treating a fly ash extract from MVA Ingolstadt containing different concentrations of HB-PEI by tangential flow ultrafiltration. The pilot plant was operated at a transmembrane pressure (TMP) of 5 bar, and the temperature in the filtration circuit was $40^{\circ} \mathrm{C}$. The water-soluble polymer was trapped inside the filtration circuit and the polymer-free permeate was led back into the feed reservoir of the pilot plant.

The influence of polymer concentration and tangential velocity on the permeate flux and specific power uptake of the pilot plant are summarized in Figure 4. Power uptake included the power consumption of the pressure and the tangential flow pump. Performance of the tangential flow filtration clearly increased with increasing tangential velocity and decreased with increasing polymer concentration in the filtration circuit.

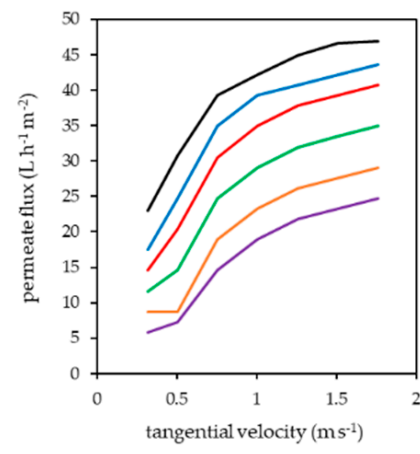

(a)

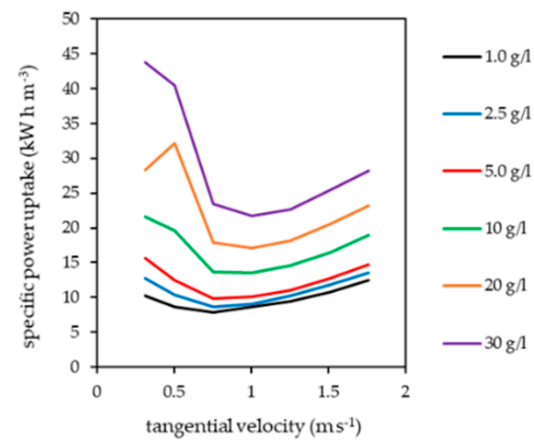

(b)

Figure 4. Influence of tangential velocity and polymer concentration on (a) permeate flux and (b) specific power consumption (pressure and cross-flow pump) of the pilot plant. HB-PEI diluted in fly ash extract. Transmembrane pressure $(\mathrm{TMP})=5 \mathrm{bar}, \mathrm{T}=40^{\circ} \mathrm{C}$. 
PAUF is influenced by gel layer formation [21-23], which occurs in the boundary layer on the membrane surface due to the retention of the water-soluble polymer. This results in additional flow resistance, decreasing the achievable permeate flux and increasing the specific power uptake of the process [35]. Gel layer formation is reduced by increased tangential velocity in tangential flow filtration, as turbulent flow conditions on the membrane surface reduce the thickness of the boundary layer [36]. Consequently, the permeate flux of the pilot plant increased with increasing tangential velocity.

The transition from laminar to turbulent flow regime in the channels of the tubular ceramic membranes appeared at tangential velocities between 0.3 and $0.8 \mathrm{~m} \mathrm{~s}^{-1}$ and was observable in a strong decrease of specific power uptake. Depending on the HB-PEI concentration, a minimum specific power uptake was observed at a tangential velocity of about $0.8 \mathrm{~m} \mathrm{~s}^{-1}\left(1-10 \mathrm{~g} \mathrm{~L}^{-1} \mathrm{HB}-\mathrm{PEI}\right)$ and $1.0 \mathrm{~m} \mathrm{~s}^{-1}$ (20 and $30 \mathrm{~g} \mathrm{~L}^{-1} \mathrm{HB}-\mathrm{PEI}$ ). With further increase of tangential velocity, the specific power uptake rose moderately. This results from the logarithmic rise of the permeate flux, but a disproportional rise of pressure loss in the filtration circuit with increasing tangential velocity occurs.

The permeate flux achieved by the pilot plant is comparable to other work [15,21-23] but rather low. Reasons for this are the very high salt content of the treated fly ash extract, the high water-soluble polymer concentration used in the filtration circuit, and a progressive fouling of the ceramic tubular membranes that were used for the treatment of PEI containing fly ash extract. Irreversible fouling (i.e., by irreversible pore blocking), which cannot be reversed by counter-flushing of the membranes, was significant, but remained in a steady state. So, the pilot plant data given in this work represent realistic conditions using ceramic tubular membranes.

\subsection{Multistage Process for Technical Scale Separation of Cu(II) from Fly Ash Extract}

A PAUF-based process for the selective separation and purification of $\mathrm{Cu}(\mathrm{II})$ was investigated, as shown in Figure 5. In the retention stage, fly ash extract and HB-PEI solution were fed to an ultrafiltration plant. $\mathrm{Cu}$ (II) was bound by the polymer and retained in the filtration circuit. A preconcentrate containing $\mathrm{Cu}$ (II) loaded HB-PEI in fly ash extract was (continuously) ejected from the filtration circuit, and the $\mathrm{Cu}$ (II) depleted permeate was discharged as wastewater. In order to improve the selectivity of $\mathrm{Cu}$ (II) toward interfering ions in the fly ash extract, the preconcentrate was purified in another ultrafiltration stage. This can be done either by thickening the preconcentrate, where the concentration of $\mathrm{Cu}$ (II) loaded polymer and therefore $\mathrm{Cu}$ (II) in the filtration circuit is enriched or by rinsing the filtration circuit with water in order to displace fly ash extract from the polymer solution. Depending on the technical realization, the steps may be done in a different order or at the same time. For $\mathrm{Cu}(\mathrm{II})$ recovery and regeneration of $\mathrm{HB}-\mathrm{PEI}$, the $\mathrm{pH}$ is decreased and $\mathrm{Cu}(\mathrm{II})$ is released from the polymer. $\mathrm{Cu}$ (II) is rinsed from the filtration circuit, producing a polymer-free $\mathrm{Cu}$ (II) concentrate. The regenerated HB-PEI solution is recirculated into the retention stage.

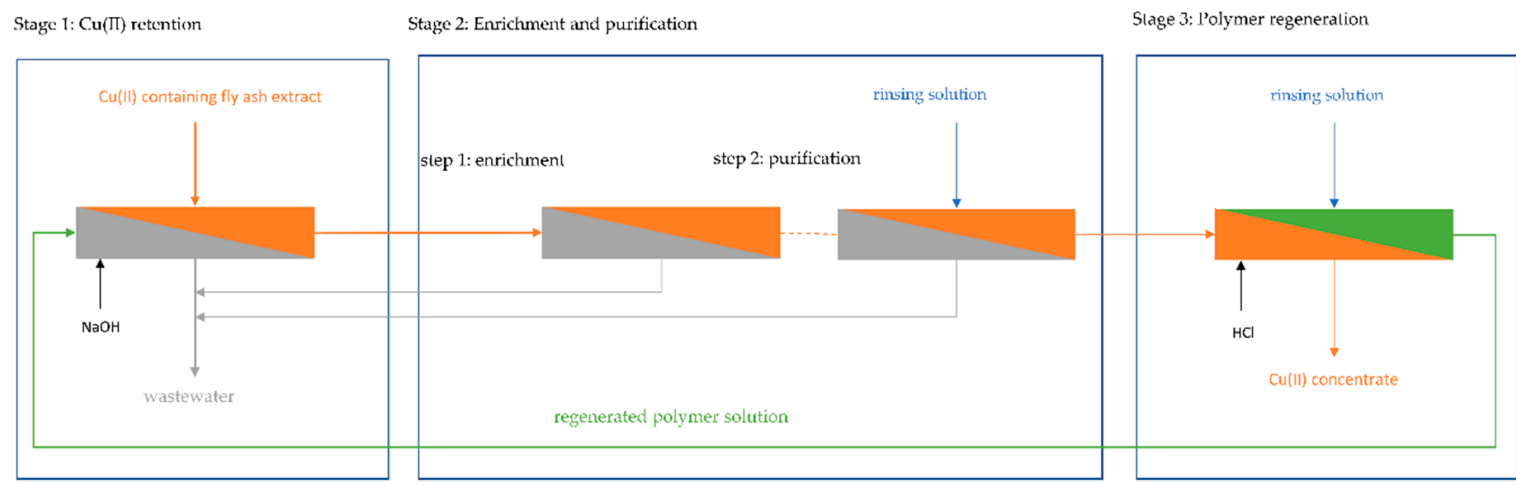

Figure 5. Multistep polymer-assisted ultrafiltration (PAUF) process for selective separation of $\mathrm{Cu}(\mathrm{II})$ from MSWI fly ash extract. A polymer-free $\mathrm{Cu}(\mathrm{II})$ concentrate is obtained in the process. 
The technical implementation of the different steps (retention, enrichment/purification, regeneration) is investigated in the following sections. The cumulative volume of solutions fed into the pilot plant is given in $\Theta$ (multiples of the filtration circuit volume). The concentration of elements in the filtration circuit is referenced to their concentration in the feed solution (in continuous operation) respective to their concentration in the filtration circuit at the beginning of the rinsing experiments (in batch operation).

\subsubsection{Retention of $\mathrm{Cu}(\mathrm{II})$ in Continuous Operation}

The retention of $\mathrm{Cu}$ (II) was investigated with two fly ash extracts containing $0.13 \mathrm{~g} \mathrm{~L}^{-1}$ and $0.7 \mathrm{~g} \mathrm{~L}^{-1} \mathrm{Cu}$ (II). The pilot plant was filled with $4 \mathrm{~g} \mathrm{~L}^{-1}$ pretreated HB-PEI in water. After startup, fly ash extract was fed to the plant and treated at $\mathrm{pH}$ 3.0. Figure 6 shows the concentrations of $\mathrm{Cu}(\mathrm{II})$, $\mathrm{Pb}(\mathrm{II}), \mathrm{Zn}(\mathrm{II})$, and $\mathrm{Ca}(\mathrm{II})$ in the filtration circuit during both experiments.

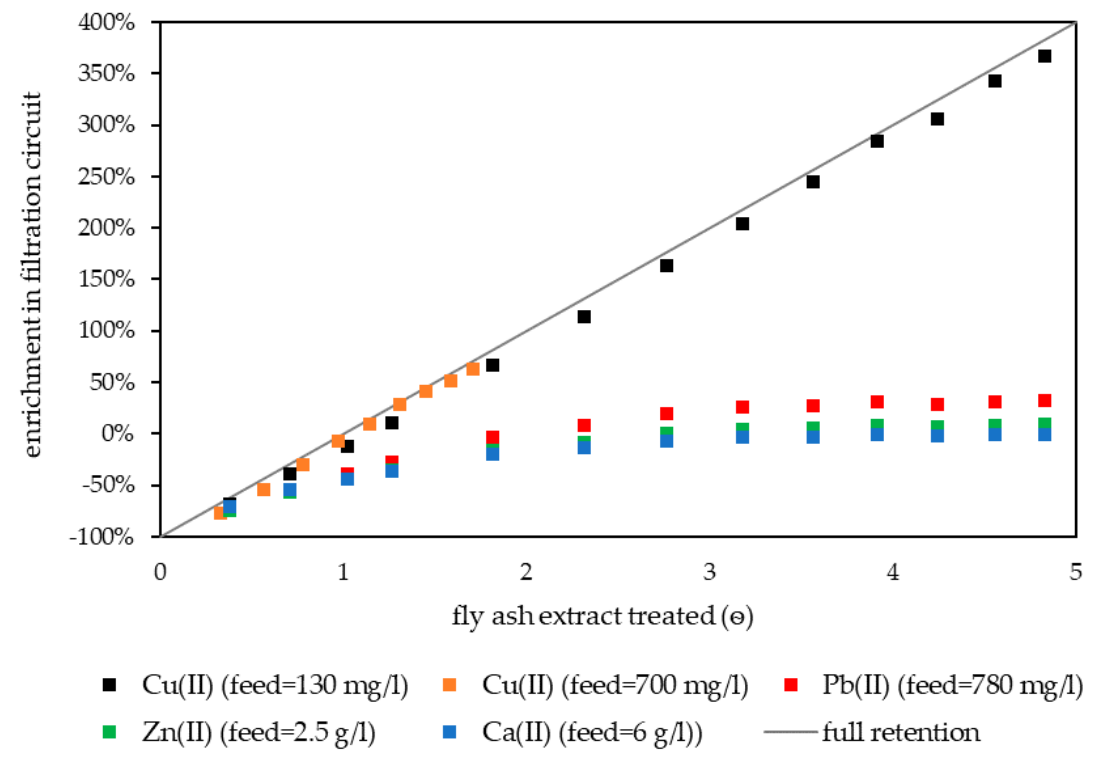

Figure 6. Enrichment of $\mathrm{Cu}(\mathrm{II}), \mathrm{Pb}(\mathrm{II}), \mathrm{Zn}$ (II), and $\mathrm{Ca}(\mathrm{II})$ in filtration circuit during continuous $\mathrm{Cu}(\mathrm{II})$ retention treating fly ash extracts from MVA Ingolstadt. The process was started with water in the filtration circuit, resulting in an arithmetically negative enrichment. Reference: concentration in the fly ash extract. HB-PEI $=4 \mathrm{~g} \mathrm{~L}^{-1}, \mathrm{pH} 3.0, \mathrm{~T}=40^{\circ} \mathrm{C}$.

At the beginning, the concentration of elements in the filtration circuit was lower than in the fly ash extract, resulting in an arithmetically negative enrichment factor. After the feed was switched to fly ash extract, the water in the filtration circuit was continuously displaced and the concentrations of $\mathrm{Cu}(\mathrm{II}), \mathrm{Zn}(\mathrm{II}), \mathrm{Pb}(\mathrm{II})$, and $\mathrm{Ca}(\mathrm{II})$ increased. After $\Theta=3, \mathrm{Ca}$ (II) concentration in the filtration circuit was equal to the $\mathrm{Ca}(\mathrm{II})$ concentration in the feed solution and therefore the enrichment was zero. This implies that the displacement of water was completed and the filtration circuit from then on was only filled with fly ash extract and HB-PEI.

$\mathrm{Ca}(\mathrm{II})$ enrichment remained zero in further operation of the pilot plant. In accordance with the laboratory experiments, $\mathrm{Ca}$ (II) was not retained in PAUF. It represents further elements that were not bound by HB-PEI at pH 3.0 which also showed zero enrichment (including chloride).

For $\mathrm{Zn}(\mathrm{II})$ and $\mathrm{Pb}(\mathrm{II})$, a slight enrichment in the filtration circuit was observed, reaching a steady state at $\Theta=4$. This slight enrichment was limited to $10 \%$ for $\mathrm{Zn}(\mathrm{II})$ and $30 \%$ for $\mathrm{Pb}(\mathrm{II})$. The latter already showed a slight binding by HB-PEI in laboratory experiments. This originates from Pb-chloro complexes interacting electrostatically with HB-PEI (see Section 3.1). At pH 3.0 Zn(II) can also form $\mathrm{Zn}$-chloro complexes (weaker compared to Pb-chloro complexes) [6]. Both metal ions do not bind to 
HB-PEI via metal complex formation at $\mathrm{pH} 3.0$ and therefore showed no linear increase in the filtration circuit in continuous operation.

In contrast, the concentration of $\mathrm{Cu}(\mathrm{II})$ in the filtration circuit correlated linearly with the volume of fly ash extract treated, irrespective of whether a feed with $0.13 \mathrm{~g} \mathrm{~L}^{-1}$ or $0.7 \mathrm{~g} \mathrm{~L}^{-1} \mathrm{Cu}$ (II) was used. With $4 \mathrm{~g} \mathrm{~L}^{-1}$ of HB-PEI, the effective $\mathrm{Cu}$ (II) concentration in the filtration circuit was limited to $0.8 \mathrm{~g} \mathrm{~L}^{-1}$ $\mathrm{Cu}$ (II) when loading of $200 \mathrm{mg} \mathrm{Cu}$ (II)/g polymer was accepted. $\mathrm{Cu}$ (II) exceeding this concentration was not sufficiently bound by HB-PEI and was lost in the following stages.

For $\mathrm{Cu}(\mathrm{II})$ retention in continuous operation, addition of sodium hydroxide solution to the filtration circuit is required, as otherwise the $\mathrm{pH}$ value drops and $\mathrm{Cu}(\mathrm{II})$ is no longer retained. The intense mixing due to the tangential flow and high buffer capacity of the polymer solution allowed perfect $\mathrm{pH}$ control in the filtration circuit. The process was able to selectively retain $\mathrm{Cu}$ (II) in the filtration circuit, even if strong fluctuation of the $\mathrm{Cu}$ (II) concentration occurred in the feed.

Though $\mathrm{Cu}(\mathrm{II})$ was enriched considerably, the achievable selectivity of $\mathrm{Cu}$ (II) toward $\mathrm{Zn}(\mathrm{II}), \mathrm{Pb}$ (II), and $\mathrm{Ca}$ (II) in a preconcentrate ejected from the filtration circuit was quite low (Table 4). In steady state, the $\mathrm{Cu}$ (II) loaded polymer was in the fly ash extract the filtration circuit was filled with. To improve $\mathrm{Cu}$ (II) selectivity, the fly ash extract had to be rinsed out from the preconcentrate in a second step.

Table 4. Concentration of $\mathrm{Pb}(\mathrm{II}), \mathrm{Zn}(\mathrm{II})$, and $\mathrm{Ca}(\mathrm{II})$ in feed solution and filtration circuit in steady state. Composition of concentrate ejected from retention step if loading of $200 \mathrm{mg} \mathrm{Cu} / \mathrm{g}$ polymer is accepted.

\begin{tabular}{cccccc}
\hline & $\mathbf{C u}(\mathrm{II})$ & $\mathbf{P b}(\mathrm{II})$ & $\mathbf{Z n}(\mathrm{II})$ & $\mathbf{C a}(\mathrm{II})$ & \\
\hline Feed solution (fly ash extract) & $0.13 / 0.70$ & 0.8 & 2.5 & 6.0 & $\mathrm{~g} \mathrm{~L}^{-1}$ \\
Steady state (filtration circuit) & - & 1.0 & 2.7 & 6.0 & $\mathrm{~g} \mathrm{~L}^{-1}$ \\
200 mg Cu/g polymer @ 4 g L L HB-PEI & 0.8 & - & - & - & $\mathrm{g} \mathrm{L}^{-1}$ \\
\hline Ejected from filtration circuit & 0.8 & 1.0 & 2.7 & 6.0 & $\mathrm{~g} \mathrm{~L}^{-1}$ \\
\hline
\end{tabular}

\subsection{2. $\mathrm{Cu}(\mathrm{II})$ Enrichment and Purification}

Rinsing of the preconcentrate with water in the batch process was investigated. The purpose of this procedure is to displace fly ash extract from the preconcentrate gained in the retention step. Due to its high concentration in the preconcentrate, $\mathrm{Ca}$ (II) concentration serves as reference for further unbound species in the filtration circuit. As can be seen in Figure 7, the concentration of $\mathrm{Ca}$ (II) followed an exponential decrease during rinsing, which can be described by Equation (2). The concentration of an unbound species in the filtration circuit decreased from the initial concentration $c_{i, 0}$ according to

$$
c_{i, \Theta}=c_{i, 0} \times e^{-\Theta}
$$

with $\Theta$ giving the volume of rinsing water used (in multiples of filtration circuit volume). An evaluation of this equation is given in Table 5 . Though slightly bound by the polymer in laboratory experiments and in the retention step, $\mathrm{Zn}(\mathrm{II})$ and $\mathrm{Pb}(\mathrm{II})$ were successfully rinsed from the filtration circuit equally to unbound species.

Table 5. Reduction of unbound species in the filtration circuit by rinsing with water (calculated by Equation (2)).

\begin{tabular}{ccccccc}
\hline Rinsing Water Used $(\mathbf{\Theta})$ & $\mathbf{0}$ & $\mathbf{1}$ & $\mathbf{2}$ & $\mathbf{3}$ & $\mathbf{4}$ & $\mathbf{5}$ \\
\hline Reduction of unbound species $\left(\mathrm{c}_{\mathrm{i}, \boldsymbol{\Theta}} / \mathrm{c}_{\mathrm{i}, 0}\right)$ & $100 \%$ & $37 \%$ & $14 \%$ & $5 \%$ & $2 \%$ & $1 \%$ \\
\hline
\end{tabular}




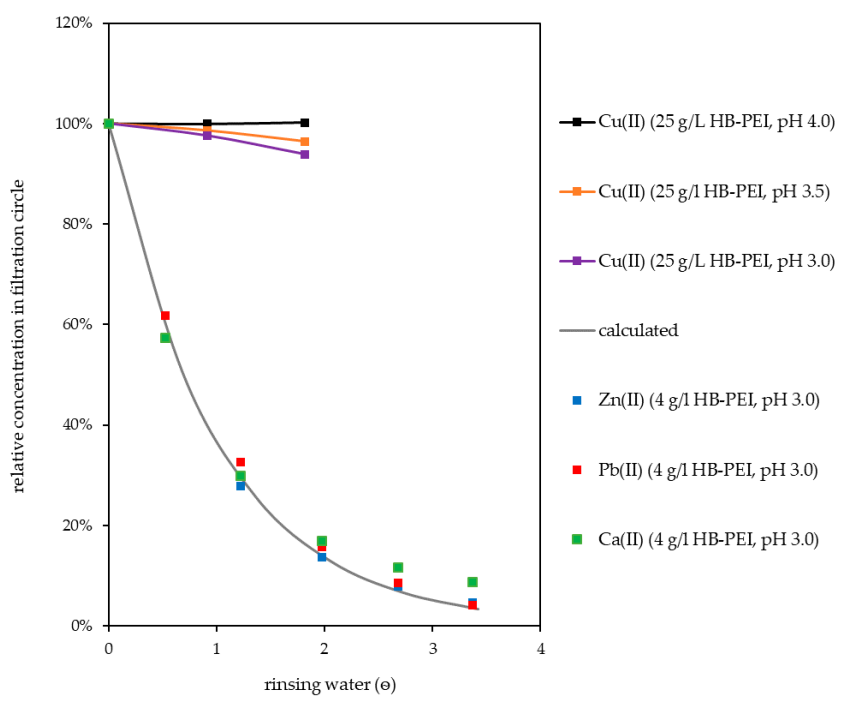

Figure 7. Rinsing of filtration circuit with water.

An alternative way to increase $\mathrm{Cu}$ (II) selectivity is to thicken the preconcentrate. This is achieved by feeding $\mathrm{Cu}$ (II) loaded preconcentrate exceeding the volume of the filtration circuit to the pilot plant. The polymer is retained by the membrane and $\mathrm{Cu}(\mathrm{II})$ is enriched linearly with increasing polymer concentration in the filtration circuit, while the concentration of unbound species passing the membrane remains equal. Combining the thickening step with purification of the concentrate obtained by rinsing with water, a substantial enhancement of $\mathrm{Cu}$ (II) selectivity toward unbound species could be obtained (Table 6).

Table 6. Enhancement of $\mathrm{Cu}$ (II) selectivity toward unbound species by increased polymer concentration (thickening) and rinsing of filtration circuit (with water); $4 \mathrm{~g} \mathrm{~L}^{-1} \mathrm{HB}-\mathrm{PEI}$ in the initial concentrate was considered.

\begin{tabular}{|c|c|c|c|c|c|c|c|}
\hline & & \multicolumn{6}{|c|}{ Rinsing with Water $(\Theta)$} \\
\hline & & 0 & 1 & 2 & 3 & 4 & 5 \\
\hline \multirow{4}{*}{$\begin{array}{l}\text { c(HB-PEI) after } \\
\text { thickening }\end{array}$} & $4 \mathrm{~g} \mathrm{~L}^{-1}$ & 1 & 3 & 7 & 20 & 55 & 148 \\
\hline & $10 \mathrm{~g} \mathrm{~L}^{-1}$ & 3 & 7 & 18 & 50 & 136 & 371 \\
\hline & $25 \mathrm{~g} \mathrm{~L}^{-1}$ & 6 & 17 & 46 & 126 & 341 & 928 \\
\hline & $50 \mathrm{~g} \mathrm{~L}^{-1}$ & 13 & 34 & 92 & 251 & 682 & 1855 \\
\hline
\end{tabular}

When the preconcentrate was rinsed at an initial $\mathrm{Cu}(\mathrm{II})$ loading of $250 \mathrm{mg} \mathrm{Cu}(\mathrm{II}) / \mathrm{g}$ polymer, a significant loss of $\mathrm{Cu}$ (II) occurred. Therefore, rinsing was optimized by reducing the initial loading to $200 \mathrm{Cu}(\mathrm{II}) / \mathrm{g}$ polymer. As can be seen in Figure 7, the $\mathrm{Cu}$ (II) concentration did not drop when rinsing was done at $\mathrm{pH} 4.0$, and only slightly decreased when the $\mathrm{pH}$ value was lowered to $3.5(96 \%)$ and $3.0(94 \%)$ during rinsing $(\Theta=1.8)$.

The very high concentration of interfering ions in the preconcentrate requires intense rinsing of the filtration circuit. It was very efficient at the beginning but dilution of the fly ash extract in the filtration circuit resulted in a steady decrease of rinsing efficiency with increasing volume of rinsing water used. High purification of the $\mathrm{Cu}$ (II) preconcentrate was accompanied by a high consumption of rinsing water and, due to the application of tangential flow ultrafiltration, energy. Using PAUF for selective enrichment and separation requires processes for further metal recovery that tolerate remaining interfering ions in the PAUF concentrate in order to minimize the required rinsing. 


\subsubsection{Regeneration of the Polymer}

Finally, regeneration of the polymer and gaining a polymer-free $\mathrm{Cu}$ (II) concentrate in a batch process were investigated. $\mathrm{Cu}(\mathrm{II})$ was released from HB-PEI by the addition of hydrochloric acid to the filtration circuit until $\mathrm{pH} 1.0$ was reached. Unbound $\mathrm{Cu}(\mathrm{II})$ was then rinsed from the filtration circuit by water. The discharge of $\mathrm{Cu}(\mathrm{II})(\Delta)$ from the filtration circuit, depending on the volume of rinsing solution used $(\Theta)$, is described with an adaption of Equation (2):

$$
\Delta=1-\frac{c_{i, \Theta}}{c_{i, 0}}=1-e^{-\Theta}
$$

Experimental and calculated data for the $\mathrm{Cu}$ (II) discharge are given in Figure 8. $\mathrm{Cu}$ (II) was efficiently discharged from the pilot plant by rinsing with water, generating a polymer-free $\mathrm{Cu}(\mathrm{II})$ concentrate. The regenerated HB-PEI remained in the filtration circuit and was used in further separation cycles.

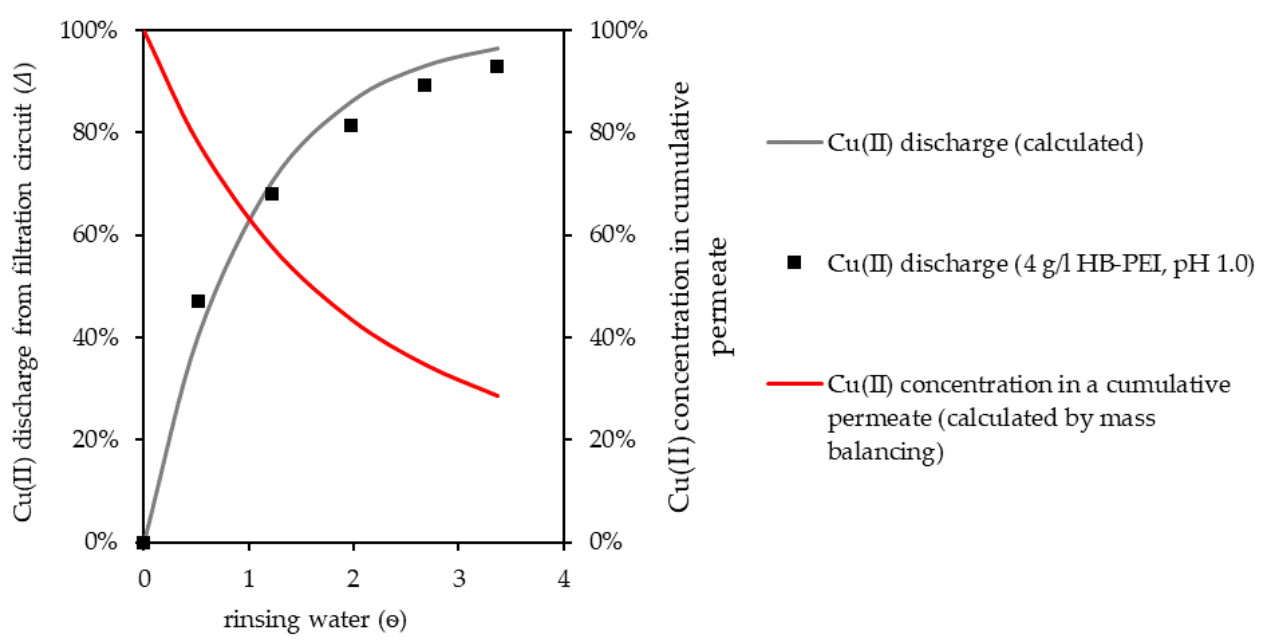

Figure 8. HB-PEI regeneration by $\mathrm{pH}$ decrease and $\mathrm{Cu}$ (II) discharge from the filtration circuit by rinsing with water. $\mathrm{Cu}(\mathrm{II})$ concentration in cumulative permeate is referenced to initial $\mathrm{Cu}(\mathrm{II})$ concentration in the filtration circuit.

Due to the decreased $\mathrm{Cu}$ (II) concentration in the filtration circuit, $\mathrm{Cu}$ (II) concentration in the accumulated polymer-free permeate steadily decreased (Figure 8, calculated by mass balancing) with increasing volume of rinsing water. As the regenerated polymer solution was supposed to be used for $\mathrm{Cu}(\mathrm{II})$ retention again, a sufficient discharge of $\mathrm{Cu}$ (II) from the filtration circuit was necessary, as remaining unbound $\mathrm{Cu}(\mathrm{II})$ in the polymer solution was recirculated to the retention step, reducing the performance of this step. Depending on the polymer concentration in the filtration circuit, $\mathrm{Cu}$ (II) concentrations in a polymer-free concentrate, as given in Table 7, can be achieved in a batch regeneration process. An initial polymer loading of $250 \mathrm{mg} \mathrm{Cu}(\mathrm{II}) / \mathrm{g}$ polymer, no $\mathrm{Cu}(\mathrm{II})$ retention during rinsing, and $90 \% \mathrm{Cu}(\mathrm{II})$ discharge are assumed.

Table 7. Final $\mathrm{Cu}(\mathrm{II})$ concentration in cumulative permeate collected during polymer regeneration and rinsing of the filtration circuit with water. $\mathrm{No} C \mathrm{Cu}(\mathrm{II})$ retention and $90 \%$ discharge $(\Theta=2.3)$ are assumed. Calculation according to Equation (3) and by mass balancing.

\begin{tabular}{ccccccc}
\hline $\mathbf{c}($ HB-PEI) & $\mathbf{4}$ & $\mathbf{1 0}$ & $\mathbf{2 5}$ & $\mathbf{5 0}$ & $\mathbf{1 0 0}$ & $\mathbf{g ~ L}^{-\mathbf{1}}$ \\
\hline Initial $\mathrm{Cu}(\mathrm{II})$ in filtration circuit & 0.8 & 2 & 5 & 10 & 20 & $\mathrm{~g} \mathrm{~L}^{-1}$ \\
Final $\mathrm{Cu}(\mathrm{II})$ in cumulative permeate & 0.3 & 0.8 & 2.0 & 3.9 & 7.8 & $\mathrm{~g} \mathrm{~L} \mathrm{~L}^{-1}$ \\
\hline
\end{tabular}




\subsection{Photometric Control of the Cu(II) Enrichment and Release}

For pilot scale operation, control of the $\mathrm{Cu}(\mathrm{II})$ enrichment and release in the filtration circuit is highly beneficial. An inline measurement of the $\mathrm{Cu}(\mathrm{II})$ enrichment enables an automated $\mathrm{pH}$ decrease by acid addition as soon as the $\mathrm{Cu}$ (II) loading of the polymer is completed. Then again, as soon as the $\mathrm{Cu}(\mathrm{II})$ release is completed, the $\mathrm{pH}$ is automatically increased and a new enrichment cycle can be started.

Therefore, the specific change in light absorption of PEI depending on its complex formation can be utilized. Due to the formation of Cu(II) complexes with HB-PEI (tetraamminecopper(II)) [37] and $\mathrm{H}_{2} \mathrm{O}$, photometric control of the enrichment and release during PAUF experiments [23] with fly ash extract was investigated.

Figure 9a shows the increasing $\mathrm{Cu}$ (II) loading of HB-PEI at pH 4.0 (feed solutions in cuvettes 1-10), followed by a clearly visible color change representing the $\mathrm{Cu}$ (II) release at $\mathrm{pH} 1.0$ (feed solution in cuvette 11). Decreasing the $\mathrm{pH}$ value, the feed solutions turned colorless to light blue again, indicating the formation of hexaaquacopper(II) and thus the regeneration of HB-PEI.

a
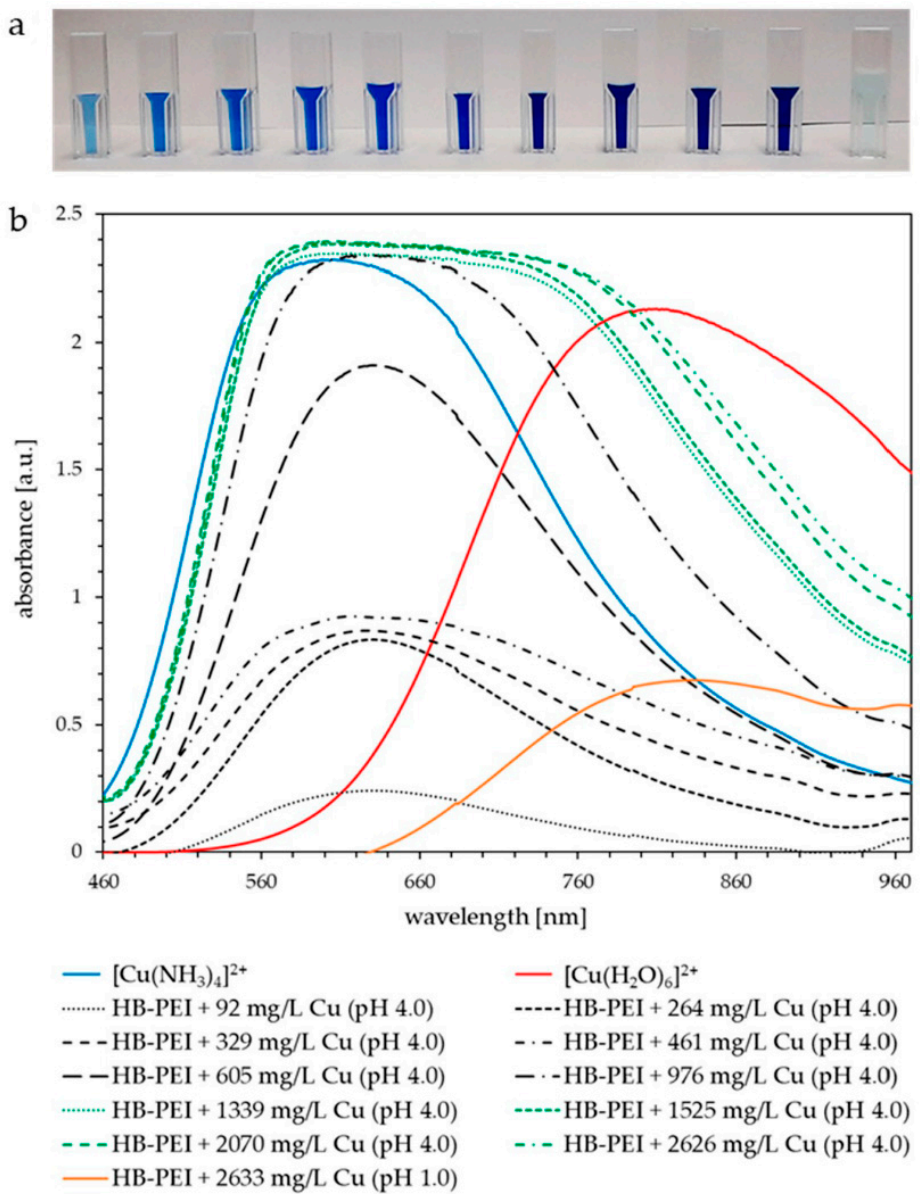

Figure 9. (a) PAUF feed samples of $\mathrm{Cu}(\mathrm{II})$ enrichment and final $\mathrm{Cu}(\mathrm{II})$ release (far right) from HB-PEI using fly ash extract (KEBAG Zuchwil), HB-PEI $=4.6 \mathrm{~g} \mathrm{~L}^{-1}$. (b) Corresponding UV-vis spectra of increasing $\mathrm{Cu}$ (II) loading (gray, black, and green graphs) and release (orange graph). Comparable solutions of $\left[\mathrm{Cu}\left(\mathrm{NH}_{3}\right)_{4}\right]^{2+}$ (blue graph) and $\left[\mathrm{Cu}\left(\mathrm{H}_{2} \mathrm{O}\right)_{6}\right]^{2+}$ (red graph) were additionally analyzed.

Figure $9 \mathrm{~b}$ shows the UV-vis spectra of the PAUF feed samples with increasing $\mathrm{Cu}(\mathrm{II})$ concentration from gray to black to green graphs. The prepared solution of $\left[\mathrm{Cu}\left(\mathrm{NH}_{3}\right)_{4}\right]^{2+}$ (Figure $9 \mathrm{~b}$, blue graph) has an absorption maximum at $605 \mathrm{~nm}$. The copper(II) ammine complex formed with HB-PEI absorbs at very similar wavelengths. The intensity of the absorption bands increases until the maximum 
loading capacity is reached at around $976 \mathrm{mg} \mathrm{L}^{-1}$ of $\mathrm{Cu}$ (II). Additional $\mathrm{Cu}$ (II) forms $\mathrm{Cu}$ (II) aqua complexes. Therefore, UV-vis spectra are shifted more to the right toward the absorption maximum of $\left[\mathrm{Cu}\left(\mathrm{H}_{2} \mathrm{O}\right)_{6}\right]^{2+}(810 \mathrm{~nm}$, red graph) and a mixture of ammine and aqua complexes occurs in the feed solution. At $\mathrm{pH} 1.0, \mathrm{Cu}(\mathrm{II})$ is released from HB-PEI and the $\mathrm{Cu}$ (II) aqua complex exists exclusively, showing an absorption maximum at $830 \mathrm{~nm}$ (Figure 9b, orange graph).

It is easy to distinguish between the absorption maxima of the ammine and aqua complexes formed within the $\mathrm{Cu}$ (II) enrichment and those obtained during the release from HB-PEI. This enables calibrated photometric control of the selective $\mathrm{Cu}$ (II) separation from real fly ash extract by PAUF.

\section{Conclusions}

In this work, the application of polymer-assisted ultrafiltration (PAUF) for selective retention and separation of $\mathrm{Cu}$ (II) from MSWI fly ash extracts was investigated at laboratory and pilot scale. The following conclusions can be drawn from these investigations:

- The results from laboratory experiments concerning the heavy metal binding of water-soluble polymers can be successfully transferred to a pilot scale process. The overall instrumental design of the PAUF process is quite simple, allowing estimations of the different process stages using basic equations. This enables an easy scale-up of PAUF processes based on laboratory and pilot experiments.

- Hyperbranched and ethoxylated PEI with moderate molecular weights are highly suitable for the selective retention of $\mathrm{Cu}$ (II) from fly ash extract. PAUF allows perfect $\mathrm{pH}$ control and highly selective $\mathrm{Cu}$ (II) retention in a continuous pilot scale process. In combination with photometric control, fluctuation of the $\mathrm{Cu}$ (II) concentration in the feed solution can be handled, allowing for a superior process control.

- In PAUF, $\mathrm{Cu}(\mathrm{II})$ retention occurs directly in the fly ash extract. The $\mathrm{Cu}(\mathrm{II})$ concentration is limited by the polymer concentration which in turn is efficiently treatable by ultrafiltration. Due to the very high concentration of interfering ions in MSWI fly ash extracts, a subsequent ultrafiltration step is needed, in which the fly ash extract is rinsed from the $\mathrm{Cu}(\mathrm{II})$ loaded polymer solution.

- Rinsing the polymer solution after the retention stage is an important but laborious step to increase $\mathrm{Cu}$ (II) selectivity. Additionally, thickening the polymer concentrate can be done for an effective increase of $\mathrm{Cu}$ (II) selectivity and overall $\mathrm{Cu}$ (II) concentration in the polymer solution. However, for metal recovery from PAUF concentrates, processes should be used that tolerate remaining fly ash extract in the concentrate, as rinsing should be minimized as far as possible.

- After regeneration by $\mathrm{pH}$ decrease as described in this work, polyethyleneimine can be reused for $\mathrm{Cu}$ (II) retention. A polymer-free $\mathrm{Cu}$ (II) concentrate is obtained, which can be used for metal production.

Supplementary Materials: The following are available online at http://www.mdpi.com/2227-9717/8/12/1662/s1: Figure S1. Schematic illustration of laboratory ultrafiltration system. Figure S2. pH dependent metal retention using fly ash extract from MVA Ingolstadt without addition of polymer. Table S1. Average metal concentrations $\left(>1 \mathrm{mg} \mathrm{L}^{-1}\right.$ ) of fly ash extracts from MVA Ingolstadt and KEBAG Zuchwil. Chloride concentration of both extracts is approximately $60 \mathrm{~g} \mathrm{~L}^{-1}$.

Author Contributions: Conceptualization, C.H. and S.F.; methodology, C.H. and S.F.; experimental investigation, C.H. and S.F.; data curation, C.H. and S.F.; writing—original draft preparation, C.H. and S.F.; writing-review and editing, C.H., S.F. and M.S.; visualization, C.H. and S.F.; project administration, M.S.; funding acquisition, M.S. All authors have read and agreed to the published version of the manuscript.

Funding: This research was funded by the German Federal Ministry of Education and Research (Bundesministerium für Bildung und Forschung, BMBF), grant number 033R140.

Acknowledgments: The authors would like to thank Anton Perfoll and Michael Funk (MVA Ingolstadt) and the staff members of KEBAG Zuchwil for providing fly ash extract samples for our research. The authors would also like to thank BASF SE for providing the polymers used in this study. 
Conflicts of Interest: The authors declare no conflict of interest. The funders had no role in the design of the study, in the collection, analyses or interpretation of data, in the writing of the manuscript or in the decision to publish the results.

\section{References}

1. Huber, F.; Simon, F.-G.; Hyks, J.; Braga, R.; Biganzoli, L.; Costa, G.; Funari, V.; Grosso, M. Metal recovery from incineration bottom ash: State-of-the-art and recent developments. J. Hazard. Mater. 2020, 393. [CrossRef]

2. Jiao, F.; Zhang, L.; Dong, Z.; Namioka, T.; Yamada, N.; Ninomiya, Y. Study on the species of heavy metals in MSW incineration fly ash and their leaching behavior. Fuel Process. Technol. 2016, 152, 108-115. [CrossRef]

3. Weibel, G.; Eggenberger, U.; Schlumberger, S.; Mäder, U.K. Chemical associations and mobilization of heavy metals in fly ash from municipal solid waste incineration. Waste Manag. 2017, 62, 147-159. [CrossRef]

4. Haberl, J.; Koralewska, R.; Schlumberger, S.; Schuster, M. Quantification of main and trace metal components in the fly ash of waste-to-energy plants located in Germany and Switzerland: An overview and comparison of concentration fluctuations within and between several plants with particular focus on valuable metals. Waste Manag. 2018, 75, 361-371. [CrossRef]

5. Fabricius, A.-L.; Renner, M.; Voss, M.; Funk, M.; Perfoll, A.; Gehring, F.; Graf, R.; Fromm, S.; Duester, L. Municipal waste incineration fly ashes: From a multi-element approach to market potential evaluation. Environ. Sci. Eur. 2020, 32, 1-14. [CrossRef]

6. Weibel, G.; Eggenberger, U.; Kulik, D.A.; Hummel, W.; Schlumberger, S.; Klink, W.; Fisch, M.; Mäder, U.K. Extraction of heavy metals from MSWI fly ash using hydrochloric acid and sodium chloride solution. Waste Manag. 2018, 76, 457-471. [CrossRef] [PubMed]

7. Ferraro, A.; Farina, I.; Race, M.; Colangelo, F.; Cioffi, R.; Fabbricino, M. Pre-treatments of MSWI fly-ashes: A comprehensive review to determine optimal conditions for their reuse and/or environmentally sustainable disposal. Rev. Environ. Sci. Bio/Technol. 2019, 18, 453-471. [CrossRef]

8. Luo, H.; Cheng, Y.; He, D.; Yang, E.-H. Review of leaching behavior of municipal solid waste incineration (MSWI) ash. Sci. Total Environ. 2019, 668, 90-103. [CrossRef] [PubMed]

9. Schlumberger, S.; Schuster, M.; Ringmann, S.; Koralewska, R. Recovery of high purity zinc from filter ash produced during the thermal treatment of waste and inerting of residual materials. Waste Manag. Res. 2007, 25, 547-555. [CrossRef]

10. Antuñano, N.; Cambra, J.; Arias, P. Hydrometallurgical processes for Waelz oxide valorisation-An overview. Process. Saf. Environ. Prot. 2019, 129, 308-320. [CrossRef]

11. Sverdrup, H.U.; Ragnarsdottir, K.V.; Koca, D. On modelling the global copper mining rates, market supply, copper price and the end of copper reserves. Resour. Conserv. Recycl. 2014, 87, 158-174. [CrossRef]

12. Elshkaki, A.; Graedel, T.; Ciacci, L.; Reck, B.K. Copper demand, supply, and associated energy use to 2050. Glob. Environ. Chang. 2016, 39, 305-315. [CrossRef]

13. Haberl, J.; Schuster, M. Solubility of elements in waste incineration fly ash and bottom ash under various leaching conditions studied by a sequential extraction procedure. Waste Manag. 2019, 87, 268-278. [CrossRef] [PubMed]

14. Crini, G.; Morin-Crini, N.; Fatin-Rouge, N.; Déon, S.; Fievet, P. Metal removal from aqueous media by polymer-assisted ultrafiltration with chitosan. Arab. J. Chem. 2017, 10, S3826-S3839. [CrossRef]

15. Huang, Y.; Feng, X. Polymer-enhanced ultrafiltration: Fundamentals, applications and recent developments. J. Membr. Sci. 2019, 586, 53-83. [CrossRef]

16. Geckeler, K.E.; Shkinev, V.M.; Spivakov, B.Y. Liquid-Phase Polymer-Based Retention (Lpr)-A New Method for Selective Ion Separation. Sep. Purif. Methods 1988, 17, 105-140. [CrossRef]

17. Chou, Y.-H.; Choo, K.-H.; Chen, S.-S.; Yu, J.-H.; Peng, C.-Y.; Li, C.-W. Copper recovery via polyelectrolyte enhanced ultrafiltration followed by dithionite based chemical reduction: Effects of solution $\mathrm{pH}$ and polyelectrolyte type. Sep. Purif. Technol. 2018, 198, 113-120. [CrossRef]

18. Kochkodan, O.D.; Kochkodan, V.M.; Sharma, V.K. Removal of $\mathrm{Cu}(\mathrm{II})$ in water by polymer enhanced ultrafiltration: Influence of polymer nature and pH. J. Environ. Sci. Heal. Part. A 2018, 53, 33-38. [CrossRef]

19. Molinari, R.; Gallo, S.; Argurio, P. Metal ions removal from wastewater or washing water from contaminated soil by ultrafiltration-complexation. Water Res. 2004, 38, 593-600. [CrossRef] 
20. Llanos, J.; Pérez, A.; Canizares, P. Copper recovery by polymer enhanced ultrafiltration (PEUF) and electrochemical regeneration. J. Membr. Sci. 2008, 323, 28-36. [CrossRef]

21. Llanos, J.; Perez, A.; Canizares, P. Water-soluble polymer ultrafiltration process at pilot scale: Study of hydrodynamics and factors limiting flux. J. Membr. Sci. 2009, 341, 37-45. [CrossRef]

22. Canizares, P. A semi-continuous laboratory-scale polymer enhanced ultrafiltration process for the recovery of cadmium and lead from aqueous effluents. J. Membr. Sci. 2004, 240, 197-209. [CrossRef]

23. Canizares, P.; De Lucas, A.; Pérez, Á.; Camarillo, R. Effect of polymer nature and hydrodynamic conditions on a process of polymer enhanced ultrafiltration. J. Membr. Sci. 2005, 253, 149-163. [CrossRef]

24. Baticle, P.; Kiefer, C.; Lakhchaf, N.; Leclerc, O.; Persin, M.; Sarrazin, J. Treatment of nickel containing industrial effluents with a hybrid process comprising of polymer complexation-ultrafiltration-electrolysis. Sep. Purif. Technol. 2000, 18, 195-207. [CrossRef]

25. Kadioglu, S.I.; Yilmaz, L.; Aydogan, N.; Ozbelge, H.O. Removal of Heavy Metals from Multicomponent Metal Mixtures by Polymer Enhanced Ultrafiltration: Effects of $\mathrm{pH}$, Ionic Strength and Conformational Changes in Polymer Structure. Sep. Sci. Technol. 2010, 45, 1363-1373. [CrossRef]

26. Gallo, D.; Acosta, E.J.; Scamehorn, J.F.; Sabatini, D.A. Pilot-scale study of Polyelectrolyte-Enhanced UF for arsenic removal. J. Am. Water Work. Assoc. 2006, 98, 106-116. [CrossRef]

27. Geckeler, K.E.; Volchek, K. Removal of Hazardous Substances from Water Using Ultrafiltration in Conjunction with Soluble Polymers. Environ. Sci. Technol. 1996, 30, 725-734. [CrossRef]

28. Schulte-Bockholt, M.; Schuster, M. Removal enrichment and recovery of Ni(II), Zn(II) and phosphate from phosphation rinsing waters with liquid-phase polymer-based retention technique. Sep. Purif. Technol. 2008, 63, 172-178. [CrossRef]

29. Tavares, C.R.G.; Vieira, M.; Petrus, J.; Bortoletto, E.; Ceravollo, F. Ultrafiltration/complexation process for metal removal from pulp and paper industry wastewater. Desalination 2002, 144, 261-265. [CrossRef]

30. Petrov, S.; Nenov, V. Removal and recovery of copper from wastewater by a complexation-ultrafiltration process. Desalination 2004, 162, 201-209. [CrossRef]

31. Krupka, K.M.; Serne, R.J. Geochemical Factors Affecting the Behavior of Antimony, Cobalt, Europium, Technetium, and Uranium in Vadose Zone Sediments, 2002, doi:10.2172/15004491. Available online: http://www.pnl.gov/main/publications/external/technical_reports/PNNL-14126.pdf (accessed on 28 November 2020).

32. Hagemann, S. Thermodynamische Eigenschaften des Bleis in Lösungen der Ozeanischen Salze. Ph.D. Thesis, Technische Universität Carolo-Wilhelmina, Braunschweig, Germany, 1999.

33. Comans, R.N.J.; Van Dijk, C.P.J. Role of complexation processes in cadmium mobilization during estuarine mixing. Nat. Cell Biol. 1988, 336, 151-154. [CrossRef]

34. Irving, H.; Williams, R.J.P. Order of Stability of Metal Complexes. Nat. Cell Biol. 1948, 162, 746-747. [CrossRef]

35. Vela, M.C.V.; Álvarez-Blanco, S.; Lora, J.; Gozálvez-Zafrilla, J.M.; Rodríguez, E.B. Modelling of flux decline in crossflow ultrafiltration of macromolecules: Comparison between predicted and experimental results. Desalination 2007, 204, 328-334. [CrossRef]

36. Rai, P.; Rai, C.; Majumdar, G.; Dasgupta, S.; De, S. Resistance in series model for ultrafiltration of mosambi (Citrus sinensis (L.) Osbeck) juice in a stirred continuous mode. J. Membr. Sci. 2006, 283, 116-122. [CrossRef]

37. Tauler, R.; Casassas, E. Spectroscopic resolution of macromolecular complexes using factor analysis: $\mathrm{Cu}(\mathrm{II})$ -polyethyleneimine system. Chemom. Intell. Lab. Syst. 1992, 14, 305-317. [CrossRef]

Publisher's Note: MDPI stays neutral with regard to jurisdictional claims in published maps and institutional affiliations.

(C) 2020 by the authors. Licensee MDPI, Basel, Switzerland. This article is an open access article distributed under the terms and conditions of the Creative Commons Attribution (CC BY) license (http://creativecommons.org/licenses/by/4.0/). 